\title{
Complementing the Pleistocene biogeography of European amphibians: Testimony from a southern Atlantic species
}

\author{
Gregorio Sánchez-Montes ${ }^{1}$ \\ Î́nigo Martínez-Solano ${ }^{1,2,4}$
}

\author{
Ernesto Recuero $^{2}$ | A. Márcia Barbosa ${ }^{3}$
}

${ }^{1}$ Ecology, Evolution, and Development Group, Department of Wetland Ecology, Doñana Biological Station, Sevilla, Spain

${ }^{2}$ Museo Nacional de Ciencias Naturales, CSIC, Madrid, Spain

${ }^{3}$ Centro de Investigação em Biodiversidade e Recursos Genéticos (CIBIO/InBIO), Universidade de Évora, Évora, Portugal

${ }^{4}$ Instituto de Investigación en Recursos Cinegéticos (IREC-CSIC-UCLM-JCCM),

Ciudad Real, Spain

\section{Correspondence}

Î́nigo Martínez-Solano, Department of Biodiversity and Evolutionary Biology, Museo Nacional de Ciencias Naturales, Madrid, Spain.

Email: inigomsolano@mncn.csic.es

\section{Funding information}

Secretaría de Estado de Investigación, Desarrollo e Innovación, Grant/Award Number: CGL2011-28300; Fundação para a Ciência e a Tecnologia, Grant/Award Number: IF/00266/2013/CP1168/CT0001; Ministerio de Ciencia e Innovación, Grant/ Award Number: CGL2008-04271-C02-01/ BOS; Ramón y Cajal, Grant/Award Number: RYC-2007-01668; Severo Ochoa, Grant/ Award Number: SEV-2012-0262; Investigador FCT, Grant/Award Number: IF/ 00266/2013/CP1168/CT0001

Editor: Krystal Tolley

\begin{abstract}
Aim: To reconstruct the historical biogeography of Hyla molleri, a tree frog endemic to the Eurosiberian and Mediterranean bioclimatic zones in the Iberian Peninsula. Location: Iberian Peninsula.

Methods: We used molecular data (mtDNA and species-specific, polymorphic microsatellite loci) and species distribution modelling (SDM) from the Last Interglacial (LIG) to the present to characterize spatial patterns of genetic diversity in this species and assess their relationship with climatically favourable areas through time. Results: Genetic diversity is heterogeneously distributed across the range of $\mathrm{H}$. molleri, with two main genetic reservoirs located in (a) central and southern Portugal and (b) a fragmented area encompassing mountainous areas in northern Spain. According to SDM, the Iberian Peninsula has experienced a progressive and continuous decrease in climatically favourable areas for $\mathrm{H}$. molleri since the LIG, especially in southern and eastern Iberia, where the species is currently absent. However, we found no correlation between areas that have remained climatically favourable since the LIG and current genetic diversity.

Main conclusions: Our results suggest that the demographic history of $\mathrm{H}$. molleri since the Pleistocene has been characterized by relative stability, contrasting with the large-scale cycles of extinction-recolonization inferred for other more thermophilous, co-distributed amphibian species in Iberia. Accounting for discordant demographic responses to climatic changes across syntopic species provides new insights about the evolutionary history of amphibian communities in southern Europe.
\end{abstract}

\section{KEYWORDS}

Holocene, Hyla molleri, integrative phylogeography, Last Glacial Maximum, Last Interglacial, microsatellites, mtDNA, species distribution modelling

\section{1 | INTRODUCTION}

Climatic instability through the Pleistocene glaciations has played a major role in shaping current patterns of intraspecific genetic diversity in many taxa endemic to southern European peninsulas, with amphibians as a particularly sensitive (and thus informative) group due to their limited dispersal capacity (Abellán \& Svenning, 2014;
Canestrelli \& Nascetti, 2008; Gonçalves et al., 2009; MartínezSolano, Teixeira, Buckley, \& García-París, 2006; Recuero \& GarcíaParís, 2011). These southern areas represent either sanctuaries (model ' $S$ ') or refugia (model ' $R$ ') for these taxa, depending on whether they harboured most or only a minor fraction of their genetic heritage respectively (Recuero \& García-París, 2011). Species with a model ' $R$ ' Pleistocene history are characterized by relatively 
shallow phylogeographic structure after the extinction of most ancient lineages during glaciations (Recuero \& García-París, 2011), whereas model ' $S$ ' species show deep phylogeographic breaks due to the persistence of ancient groups in multiple refugia (Gonçalves et al., 2015; Martínez-Solano et al., 2006). The effects of successive glacial and interglacial periods on current patterns of genetic diversity across taxa have been largely mediated by range contractions and expansions, whose relative timing is expected to differ in coldtolerant (e.g. associated with the Eurosiberian bioclimatic realm) and thermophilous (e.g. Mediterranean) taxa. In the present, model ' $S$ ' and model ' $R$ ' Eurosiberian and Mediterranean species can be found in sympatry in some areas of southern Europe, potentially showing contrasting historical demographic dynamics associated to their different Pleistocene biogeography and ecological requirements (Dufresnes et al., 2013). This can be assessed through the integration of phylogeographic analyses on multilocus genetic datasets, and species distribution modelling (SDM) representing climatic favourability in different time periods, to unravel the effects of past climate fluctuations on biodiversity (Buckley, 2009; Elith \& Leathwick, 2009).

Recent studies have applied this approach to two thermophilous Mediterranean amphibians from the Iberian Peninsula, one corresponding to a model ' $\mathrm{R}$ ' species (Pelobates cultripes, see GutiérrezRodríguez, Barbosa, \& Martínez-Solano, 2017a) and the other to a model 'S' species (Pleurodeles waltl, see Gutiérrez-Rodríguez, Barbosa, \& Martínez-Solano, 2017b). In both cases, the results showed a decrease in climatically favourable areas in the Last Glacial Maximum (LGM), associated with a decrease in genetic diversity in areas more subject to changes in favourability through time, mostly in northern latitudes (Gutiérrez-Rodríguez et al., 2017a, 2017b), supporting the idea that thermophilous Mediterranean species fit the classical model of range contraction to glacial refugia, followed by range expansion after the LGM (Gutiérrez-Rodríguez et al., 2017a, 2017b). However, the generality of this model needs to be assessed in a wider range of co-distributed taxa, including those that are also present in the cooler Atlantic region. These taxa often reach higher latitudes and altitudes than their Mediterranean counterparts, presumably because of a higher tolerance to cold environments. This higher ecological breadth may have played a role in buffering the demographic effects of the ice ages on Atlantic taxa, which would thus be less dependent on climatic stability than Mediterranean taxa, perhaps undergoing historical population dynamics differing from the classical contraction-expansion model. Characterizing the genetic structure of Eurosiberian species in southern European refugia in relation to past climatic scenarios is thus essential to obtain a comprehensive picture of the biogeographic history of Europe since the last ice age, and to understand community dynamics associated with long-term climatic changes (Lobo, Martínez-Solano, \& Sanchiz, 2016).

The Iberian tree frog Hyla molleri Bedriaga, 1889 is an optimal model system in this respect. It has a wide distribution in the Iberian peninsula, encompassing both its Eurosiberian and Mediterranean regions, and occurring from altitudes near sea level to over $2,400 \mathrm{~m}$ in the Sistema Central mountains (Reino et al., 2017). It can be considered a cold-tolerant species, with some populations inhabiting areas with annual mean temperatures below $8^{\circ} \mathrm{C}$ (Llusia, Márquez, Beltrán, Benítez, \& do Amaral, 2013). It is also a vagile species which shows a relatively high frequency of movements between distant breeding sites, as compared to other amphibians (>700 m apart, see Sánchez-Montes, Wang, Ariño, \& Martínez-Solano, 2018). Both features are probably important in driving population responses of $H$. molleri to climatic fluctuations, potentially leading to different dynamics compared to less vagile, more thermophilous species. Although previous studies on $\mathrm{H}$. molleri revealed limited genetic variation based on mitochondrial DNA (mtDNA) data, with no obvious patterns of population structure (Barth et al., 2011; Gvoždík et al., 2015; Stöck et al., 2012), its historical demography under past climatic scenarios remains to be explored in detail.

Here we use specific microsatellite markers (Sánchez-Montes, Ariño, Vizmanos, Wang, \& Martínez-Solano, 2017) and apply an integrative phylogeographic approach to reconstruct the historical biogeography of this species in Iberia. We analyse genetic samples (mtDNA and microsatellites) from 60 populations, and use SDM to infer changes in climatic favourability for this species through time, focusing on the relationship between spatial patterns of genetic diversity and historical climatic favourability. Specifically, we aim to (a) infer range-wide patterns of genetic variation and structure in $H$. molleri and assess whether they fit an ' $\mathrm{R}$ ' or an ' $\mathrm{S}$ ' model and (b) test whether genetic diversity is concentrated in areas that have remained climatically favourable since the Last Interglacial (LIG), with gradients of decreasing genetic diversity towards recently recolonized territories, in agreement with the glacial-refugium model. Alternatively, a decoupling between spatial patterns of genetic diversity and climatic stability in the Iberian refugium would support a different scenario, in which climatic changes during the Pleistocene did not have significant effects on this species' historical population dynamics. Our results have implications for the conservation of the evolutionary potential in H. molleri (Carvalho et al., 2017).

\section{2 | MATERIALS AND METHODS}

\subsection{Sampling and DNA purification}

We collected tissue samples of 248 individuals of $H$. molleri from 60 localities, covering its entire distribution range (Table 1, Figures 1 and 2). Samples included tail tips of tadpoles and toes of post-metamorphic individuals, which were then released back in the place of capture, and from specimens preserved in museum collections. Tissue samples were stored in absolute ethanol and kept at $4^{\circ} \mathrm{C}$ upon genomic DNA isolation, which was performed with NucleoSpin Tissue-Kits (Macherey-Nagel, Düren, Germany).

\section{2 | Mitochondrial DNA}

We sequenced fragments of the mitochondrial genes cytochrome $b$ (cob) and NADH dehydrogenase subunits 4 (ND4) and 5 (ND5), including adjoining tRNAs (total: 3,290 base pairs), in 247 individual samples from 59 different localities (Table 1), using primers LO and 
TABLE 1 Sample localities included in this study, with their geographical coordinates in decimal degrees (Lat: latitude, Long: longitude), the codes of individual samples of Hyla molleri and genetic diversity results obtained in mitochondrial (mtDNA) and microsatellite analyses

\begin{tabular}{|c|c|c|c|c|c|c|c|c|c|c|c|c|}
\hline \multirow[b]{2}{*}{ ID } & \multirow[b]{2}{*}{ Locality } & \multirow[b]{2}{*}{ Lat } & \multirow[b]{2}{*}{ Long } & \multirow{2}{*}{$\begin{array}{l}\text { Sample } \\
\text { codes }\end{array}$} & \multicolumn{3}{|c|}{ mtDNA } & \multicolumn{5}{|c|}{ Microsatellites } \\
\hline & & & & & $n$ & Haplotypes & $\pi$ & $n$ & AR & $H_{\circ}$ & $H_{\mathrm{E}}$ & PA \\
\hline 1 & Cuchía, Cantabria, Spain & 43.431 & -4.029 & IMS4690-IMS4699 & 10 & $\mathrm{H} 160-\mathrm{H} 162$ & 0.00023 & 9 & 2.556 & 0.382 & 0.399 & 1 \\
\hline 3 & Villaviciosa, Asturias, Spain & 43.523 & -5.380 & $\begin{array}{l}\text { IMS4701-IMS4704, } \\
\text { IMS4854 }\end{array}$ & 5 & $\begin{array}{l}\mathrm{H} 71, \mathrm{H} 163 \\
\mathrm{H} 164\end{array}$ & 0.00441 & 5 & 3.167 & 0.486 & 0.464 & 4 \\
\hline 5 & Larués, Huesca, Spain & 42.517 & -0.848 & ERG29-ERG30 & 2 & $\mathrm{H} 82, \mathrm{H} 83$ & & 1 & 1.444 & 0.500 & 0.250 & 0 \\
\hline 6 & Valgañón, La Rioja, Spain & 42.327 & -3.089 & IMS3856-IMS3861 & 6 & H90, H116-H119 & 0.00069 & 3 & 2.889 & 0.667 & 0.530 & 2 \\
\hline 7 & Cernégula, Burgos, Spain & 42.639 & -3.624 & MNCN11078 & 1 & $\mathrm{H} 169$ & & 1 & 1.556 & 0.611 & 0.306 & 0 \\
\hline 11 & Albires, León, Spain & 42.276 & -5.280 & IMS3055-IMS3060 & 6 & $\mathrm{H} 92-\mathrm{H} 97$ & 0.00108 & 3 & 2.500 & 0.602 & 0.483 & 0 \\
\hline 12 & Ólvega, Soria, Spain & 41.752 & -1.962 & IMS4097-IMS4106 & 10 & H90, H129-H137 & 0.00066 & 3 & 3.111 & 0.574 & 0.549 & 1 \\
\hline 13 & $\begin{array}{r}\text { Renales-Laranueva, } \\
\text { Guadalajara, Spain }\end{array}$ & 40.934 & -2.540 & ERG957-ERG962 & 6 & H84-H89 & 0.00079 & 3 & 2.556 & 0.657 & 0.482 & 2 \\
\hline 14 & Codesal, Zamora, Spain & 41.972 & -6.387 & $\begin{array}{l}\text { IMS4214-IMS4220, } \\
\text { IMS4222-IMS4226 }\end{array}$ & 12 & $\begin{array}{r}\mathrm{H} 142, \mathrm{H} 145, \\
\mathrm{H} 149-\mathrm{H} 158\end{array}$ & 0.00090 & 3 & 3.000 & 0.611 & 0.498 & 1 \\
\hline 15 & $\begin{array}{l}\text { Buenache de la Sierra, } \\
\text { Cuenca, Spain }\end{array}$ & 40.179 & -1.943 & IMS4157-IMS4166 & 10 & $\mathrm{H} 138-\mathrm{H} 141$ & 0.00036 & 3 & 2.667 & 0.537 & 0.467 & 0 \\
\hline 16 & $\begin{array}{l}\text { Valdemanco, } \\
\text { Madrid, Spain }\end{array}$ & 40.853 & -3.644 & $\begin{array}{l}\text { JF318126-JF318127, } \\
\text { GSH399 }, \text { GSH428 } \\
\text { GSH469 }\end{array}$ & 2 & $\mathrm{H} 168$ & & 3 & 3.278 & 0.630 & 0.519 & 2 \\
\hline 20 & Fuenterrebollo, Segovia, Spain & 41.326 & -3.926 & $\begin{array}{l}\mathrm{GSH} 554^{\mathrm{a}}, \mathrm{GSH} 557^{\mathrm{a}} \text {, } \\
\mathrm{GSH} 565^{\mathrm{a}}\end{array}$ & & & & 3 & 3.000 & 0.574 & 0.494 & 1 \\
\hline 21 & Peñalara, Madrid, Spain & 40.848 & -3.949 & MNCN3448 & 1 & $\mathrm{H} 171$ & & 1 & 1.667 & 0.722 & 0.361 & 0 \\
\hline 22 & Candeleda, Ávila, Spain & 40.126 & -5.221 & MNCN11086 & 1 & $\mathrm{H} 170$ & & 1 & 1.556 & 0.611 & 0.306 & 1 \\
\hline 23 & $\begin{array}{l}\text { Ferreras de Arriba- } \\
\text { Villardeciervos, } \\
\text { Zamora, Spain }\end{array}$ & 41.904 & -6.229 & $\begin{array}{l}\text { IMS4206-IMS4212, } \\
\text { IMS4264-IMS4265, } \\
\text { IMS4267 }\end{array}$ & 10 & $\begin{array}{l}\text { H90, H142- } \\
\text { H148, H157, } \\
\text { H159 }\end{array}$ & 0.00057 & 3 & 3.000 & 0.713 & 0.539 & 2 \\
\hline 24 & El Puerto, Asturias, Spain & 43.024 & -6.229 & $\begin{array}{l}\text { MNCN41176- } \\
\text { MNCN41183 }\end{array}$ & 8 & $\mathrm{H} 172-\mathrm{H} 178$ & 0.00203 & 1 & 1.167 & 0.500 & 0.250 & 0 \\
\hline 25 & $\begin{array}{l}\text { Monforte de Lemos, } \\
\text { Lugo, Spain }\end{array}$ & 42.529 & -7.575 & IMS3534-IMS3537 & 4 & H90, H105-H107 & 0.00123 & 3 & 3.222 & 0.694 & 0.569 & 1 \\
\hline 26 & Ginzo de Limia, Ourense, Spain & 42.054 & -7.821 & IMS3549-IMS3554 & 6 & $\mathrm{H} 110-\mathrm{H} 115$ & 0.00249 & 3 & 2.778 & 0.583 & 0.481 & 5 \\
\hline 27 & Boticas, Vila Real, Portugal & 41.689 & -7.665 & GVA212-GVA213 & 2 & $\mathrm{H} 90, \mathrm{H} 91$ & & 2 & 2.611 & 0.611 & 0.500 & 3 \\
\hline 28 & Serra da Estrela, Guarda, Portugal & 40.342 & -7.622 & $\begin{array}{l}\text { ESTR1-ESTR2, } \\
\text { IMS3555-IMS3559, } \\
\text { IMS4235-IMS4237 }\end{array}$ & 10 & $\begin{array}{l}\mathrm{H} 8, \mathrm{H} 13, \\
\mathrm{H} 40, \mathrm{H} 65\end{array}$ & 0.00046 & 6 & 3.167 & 0.533 & 0.528 & 6 \\
\hline 29 & Paramos, Aveiro, Portugal & 40.980 & -8.645 & IMS3542-IMS3545 & 4 & $\mathrm{H} 33-\mathrm{H} 36$ & 0.00451 & 3 & 3.000 & 0.611 & 0.528 & 6 \\
\hline
\end{tabular}


TABLE 1 (Continued)

\begin{tabular}{|c|c|c|c|c|c|c|c|c|c|c|c|c|}
\hline \multirow[b]{2}{*}{ ID } & \multirow[b]{2}{*}{ Locality } & \multirow[b]{2}{*}{ Lat } & \multirow[b]{2}{*}{ Long } & \multirow{2}{*}{$\begin{array}{l}\text { Sample } \\
\text { codes }\end{array}$} & \multicolumn{3}{|c|}{ mtDNA } & \multicolumn{5}{|c|}{ Microsatellites } \\
\hline & & & & & $n$ & Haplotypes & $\pi$ & $n$ & AR & $H_{\mathrm{O}}$ & $H_{\mathrm{E}}$ & PA \\
\hline 30 & Mindelo, Porto, Portugal & 41.305 & -8.723 & $\begin{array}{l}\text { IMS3546-IMS3548, } \\
\text { MIND1 }\end{array}$ & 4 & $\begin{array}{l}\mathrm{H} 37-\mathrm{H} 39, \\
\mathrm{H} 75\end{array}$ & 0.00205 & 3 & 0.889 & 0.148 & 0.142 & 0 \\
\hline 31 & $\begin{array}{l}\text { Ciudad Rodrigo, } \\
\text { Salamanca, Spain }\end{array}$ & 40.569 & -6.576 & IMS3538-IMS3539 & 2 & H108, H109 & & 2 & 1.833 & 0.472 & 0.340 & 0 \\
\hline 32 & $\begin{array}{l}\text { Lavariz, } 7.5 \mathrm{~km} \mathrm{NW} \text { of } \\
\text { Arzila, Coimbra, Portugal }\end{array}$ & 40.196 & -8.642 & IMS1447-IMS1452 & 6 & $\mathrm{H} 16-\mathrm{H} 19$ & 0.00271 & 3 & 4.111 & 0.722 & 0.685 & 5 \\
\hline 33 & Longueira, Beja, Portugal & 37.672 & -8.777 & $\begin{array}{l}\text { IMS4171, IMS4176- } \\
\text { IMS4185 }\end{array}$ & 11 & $\begin{array}{l}\mathrm{H} 8, \mathrm{H} 56- \\
\mathrm{H} 64\end{array}$ & 0.00318 & 4 & 3.778 & 0.546 & 0.604 & 9 \\
\hline 34 & $\begin{array}{l}7 \text { km NW of São José da } \\
\text { Lamarosa, Santarém, Portugal }\end{array}$ & 39.125 & -8.513 & $\begin{array}{l}\text { ERG1275-ERG1276, } \\
\text { ERG1285-ERG1286 }\end{array}$ & 4 & $\begin{array}{l}\mathrm{H} 6, \mathrm{H} 7 \\
\mathrm{H} 11, \mathrm{H} 12\end{array}$ & 0.00231 & 3 & 3.389 & 0.620 & 0.601 & 7 \\
\hline 35 & $\begin{array}{l}\text { Serra de Montejunto, } \\
\text { Lisboa, Portugal }\end{array}$ & 39.174 & -9.018 & ERG1280-ERG1284 & 5 & $\mathrm{H} 8-\mathrm{H} 10$ & 0.00055 & 5 & 3.556 & 0.642 & 0.594 & 4 \\
\hline 38 & $\begin{array}{l}\text { Castelo de Vide, } \\
\text { Portalegre, Portugal }\end{array}$ & 39.415 & -7.457 & MNCN8932 & & & & 1 & 1.222 & 0.389 & 0.194 & 1 \\
\hline 39 & $\begin{array}{l}\text { Navas de Estena, } \\
\text { Ciudad Real, Spain }\end{array}$ & 39.497 & -4.541 & IMS2166-IMS2171 & 6 & $\begin{array}{l}\mathrm{H} 8, \mathrm{H} 2 \mathrm{O}- \\
\mathrm{H} 22\end{array}$ & 0.00122 & 3 & 2.778 & 0.574 & 0.485 & 1 \\
\hline 40 & Fontanosas, Ciudad Real, Spain & 38.805 & -4.572 & IMS3816, IMS3821 & 2 & $\mathrm{H} 8, \mathrm{H} 43$ & & 1 & 1.278 & 0.389 & 0.194 & 2 \\
\hline 41 & $\begin{array}{l}\text { Río Montoro, } \mathrm{N} \text { of } \\
\text { Fuencaliente, } \\
\text { Ciudad Real, Spain }\end{array}$ & 38.498 & -4.291 & IMS3049-IMS3054 & 6 & $\mathrm{H} 27-\mathrm{H} 32$ & 0.00265 & 3 & 2.889 & 0.546 & 0.515 & 2 \\
\hline 42 & $\begin{array}{l}\text { Los Baños de Robledillo, } \\
\text { Toledo, Spain }\end{array}$ & 39.497 & -4.358 & IMS4498 & 1 & $\mathrm{H} 66$ & & 1 & 1.444 & 0.556 & 0.278 & 1 \\
\hline 46 & Coruche, Santarém, Portugal & 38.999 & -8.519 & CORU1-CORU2 & 2 & H3 & & & & & & \\
\hline 47 & Lourinhã, Lisboa, Portugal & 39.279 & -9.275 & LRNH1 & 1 & $\mathrm{H} 74$ & & & & & & \\
\hline 48 & $\begin{array}{l}\text { Beira, } \mathrm{N} \text { of Marvão, } \\
\text { Portalegre, Portugal }\end{array}$ & 39.451 & -7.360 & FJ226918 & 1 & $\mathrm{H} 15$ & & & & & & \\
\hline 49 & $\begin{array}{l}\text { Monte Claro, } \\
\text { Portalegre, Portugal }\end{array}$ & 39.532 & -7.720 & ERG104-ERG105 & 2 & $\mathrm{H} 4, \mathrm{H} 5$ & & & & & & \\
\hline 50 & Pombal, Leiria, Portugal & 39.994 & -8.683 & POM2 & 1 & $\mathrm{H} 80$ & & & & & & \\
\hline 51 & Alfarelos, Coimbra, Portugal & 40.158 & -8.667 & COIM1-COIM2 & 2 & $\mathrm{H} 1, \mathrm{H} 2$ & & & & & & \\
\hline 52 & $\begin{array}{l}\text { Cadalso de los Vidrios, } \\
\text { Madrid, Spain }\end{array}$ & 40.317 & -4.381 & MS 01a2 & 1 & $\mathrm{H} 77$ & & & & & & \\
\hline 53 & El Tiemblo, Ávila, Spain & 40.411 & -4.468 & MS 02a2-MS 05a2 & 4 & $\begin{array}{l}\mathrm{H} 78, \mathrm{H} 79, \\
\mathrm{H} 179, \mathrm{H} 180\end{array}$ & 0.00638 & & & & & \\
\hline 54 & El Hoyo de Pinares, Ávila, Spain & 40.486 & -4.390 & MS 06a2 & 1 & $\mathrm{H} 180$ & & & & & & \\
\hline 55 & $\begin{array}{l}\text { Serradilla del Llano, } \\
\text { Salamanca, Spain }\end{array}$ & 40.500 & -6.350 & PFRA1 & 1 & $\mathrm{H} 181$ & & & & & & \\
\hline 56 & Cerceda, Madrid, Spain & 40.719 & -3.956 & WP211 & 1 & H184 & & & & & & \\
\hline 57 & $\begin{array}{l}\text { Guadalix de la Sierra, } \\
\text { Madrid, Spain }\end{array}$ & 40.756 & -3.676 & WP205 & 1 & H182 & & & & & & \\
\hline
\end{tabular}


TABLE 1 (Continued)

\begin{tabular}{|c|c|c|c|c|c|c|c|c|c|c|c|c|}
\hline \multirow[b]{2}{*}{ ID } & \multirow[b]{2}{*}{ Locality } & \multirow[b]{2}{*}{ Lat } & \multirow[b]{2}{*}{ Long } & \multirow{2}{*}{$\begin{array}{l}\text { Sample } \\
\text { codes }\end{array}$} & \multicolumn{3}{|c|}{ mtDNA } & \multicolumn{5}{|c|}{ Microsatellites } \\
\hline & & & & & $n$ & Haplotypes & $\pi$ & $n$ & AR & $H_{\mathrm{O}}$ & $H_{\mathrm{E}}$ & PA \\
\hline 58 & Trancoso, Guarda, Portugal & 40.826 & -7.358 & TRAN2 & 1 & H81 & & & & & & \\
\hline 60 & La Mierla, Guadalajara, Spain & 40.923 & -3.261 & WP200 & 1 & $\mathrm{H} 85$ & & & & & & \\
\hline 62 & El Berrueco, Madrid, Spain & 40.932 & -3.569 & WP207 & 1 & $\mathrm{H} 90$ & & & & & & \\
\hline
\end{tabular}

$n$ : sample size, $\pi$ : nucleotide diversity (calculated using only full sequences, i.e. with no missing data), AR: mean allelic richness; $H_{\mathrm{O}}$ : observed heterozygosity, $H_{\mathrm{E}}$ : expected heterozygosity. PA: private alleles.

aGenotypes extracted from Sánchez-Montes et al. (2017).

H1046 for cob (Stöck et al., 2008) and newly designed primers HylaND4F-HylaND4R2 and HylaND5F2-HylaND5R1 for ND4 and ND5 respectively. We checked for stop codons to verify that sequences are indeed from mitochondrial genes and not nuclear copies or pseudogenes. Primer sequences and PCR conditions are described in Supporting Information Appendix S1. New mtDNA sequences of $\mathrm{H}$. molleri have been deposited in GenBank under accession numbers MK172097-MK172750. We calculated the number of haplotypes with FABox 1.41 (Villesen, 2007), and used individuals with complete sequences (i.e. without missing data) to calculate nucleotide diversity with DNASP v6 (Rozas et al., 2017) and to reconstruct a haplotype network with POPART 1.7 (Leigh \& Bryant, 2015), using the median-joining algorithm (Bandelt, Forster, \& Röhl, 1999).

Reconstructing time-calibrated gene trees requires information from the fossil record or on nucleotide substitution rates. We estimated substitution rates in our mtDNA sequences in a species-tree analysis in *BEAST 1.8.4 (Heled \& Drummond, 2010). This analysis included sequences from four species: Hyla meridionalis, Hyla arborea, Hyla orientalis and $H$. molleri. In addition to sequences from our targeted mtDNA fragments, we downloaded from GenBank sequences from three nuclear markers: RAG1, alpha fibrinogen and med15 (alignments and accession numbers in Supporting Information Appendix S1). For *BEAST analyses we chose the Yule process as the species tree prior and applied a calibration for the root with a prior defined by a lognormal distribution $(M=22.0, S D=0.22$, offset $=0.0$, meanlnRealSpace $=$ true), encompassing the range of divergence times between $H$. meridionalis and $H$. arborea (14.332.7 Myr) estimated in different studies compiled in TimeTree (www.timetree.org). We specified nucleotide substitution models separately for the mtDNA fragment and for each of the nuclear genes, based on results from JModelTEST 2.1.5 (Darriba, Taboada, Doallo, \& Posada, 2012). We used uninformative gamma priors for the respective clock rates in mtDNA and for each of the nuclear genes $($ shape $=0.01$, scale $=100$ ). We ran two analyses for 100 million generations and assessed convergence of parameter estimates within and across runs with Tracer 1.6 (Rambaut, Drummond, Xie, Baele, \& Suchard, 2018).

We used continuous diffusion analyses as implemented in BEAST to infer phylogenetic relationships between haplogroups and historical demographic dynamics in $H$. molleri. These analyses included all individuals sequenced for the mtDNA fragments, and incorporated information on nucleotide substitution rates as inferred in the *BEAST analysis (median $=0.0086$ substitutions $/$ site/ Myr, 95\% highest posterior density interval $=0.0039-0.0142$ ) with a lognormal prior $(M=0.008, S D=0.3$, offset $=0.0$, meanlnRealSpace $=$ true). We specified the Bayesian Skyline as the coalescent tree model (Drummond, Rambaut, Shapiro, \& Pybus, 2005). We divided the mitochondrial dataset in three major partitions and considered additional subpartitions by codon in coding regions. The optimal data partitioning scheme and respective nucleotide substitution models were selected with PARTITIONFINDER 1.1.1 (Lanfear, Calcott, Ho, \& Guindon, 2012). We ran the analysis for 300 million generations and assessed convergence of parameter estimates with TRACER. A maximum clade credibility tree based on median node heights was reconstructed with TREEANNOTATOR 1.8.4 (part of the BEAST package) and subsequently used to infer diffusion dynamics with SPREAD 1.0.6 (Bielejec, Rambaut, Suchard, \& Lemey, 2011).

We calculated several genetic estimators commonly used to detect signatures of demographic expansion in DNA sequences, such as Fu \& Li's $F$ and $D$ (Fu \& Li, 1993), Fu's $F_{\mathrm{S}}$ (Fu, 1997), Tajima's $D$ (Tajima, 1989) and Ramos-Onsins \& Rozas' $R_{2}$ (Ramos-Onsins \& Rozas, 2002), as calculated by DNASP. Test statistics were calculated both for the complete dataset and for partial datasets comprising the North-Plateau and the South+Atlantic mtDNA clades (see Section 3).

\section{3 | Microsatellites}

A set of 18 microsatellites specifically optimized for $H$. molleri (Sánchez-Montes et al., 2017) was used to genotype 113 individuals from 40 localities (Table 1). Dye-labelled primers were arranged in five multiplex reactions, which were run following the protocols reported in Sánchez-Montes, Recuero, Gutiérrez-Rodríguez, GomezMestre, and Martínez-Solano (2016), Sánchez-Montes et al. (2017). Chromatograms were obtained with an ABI PRISM 3730 sequencer using a GeneScan 500 LIZ size standard (Applied Biosystems). Alleles were scored manually using GenEMAPPER v4.0 (Applied Biosystems). The resulting dataset was complemented with 12 additional 


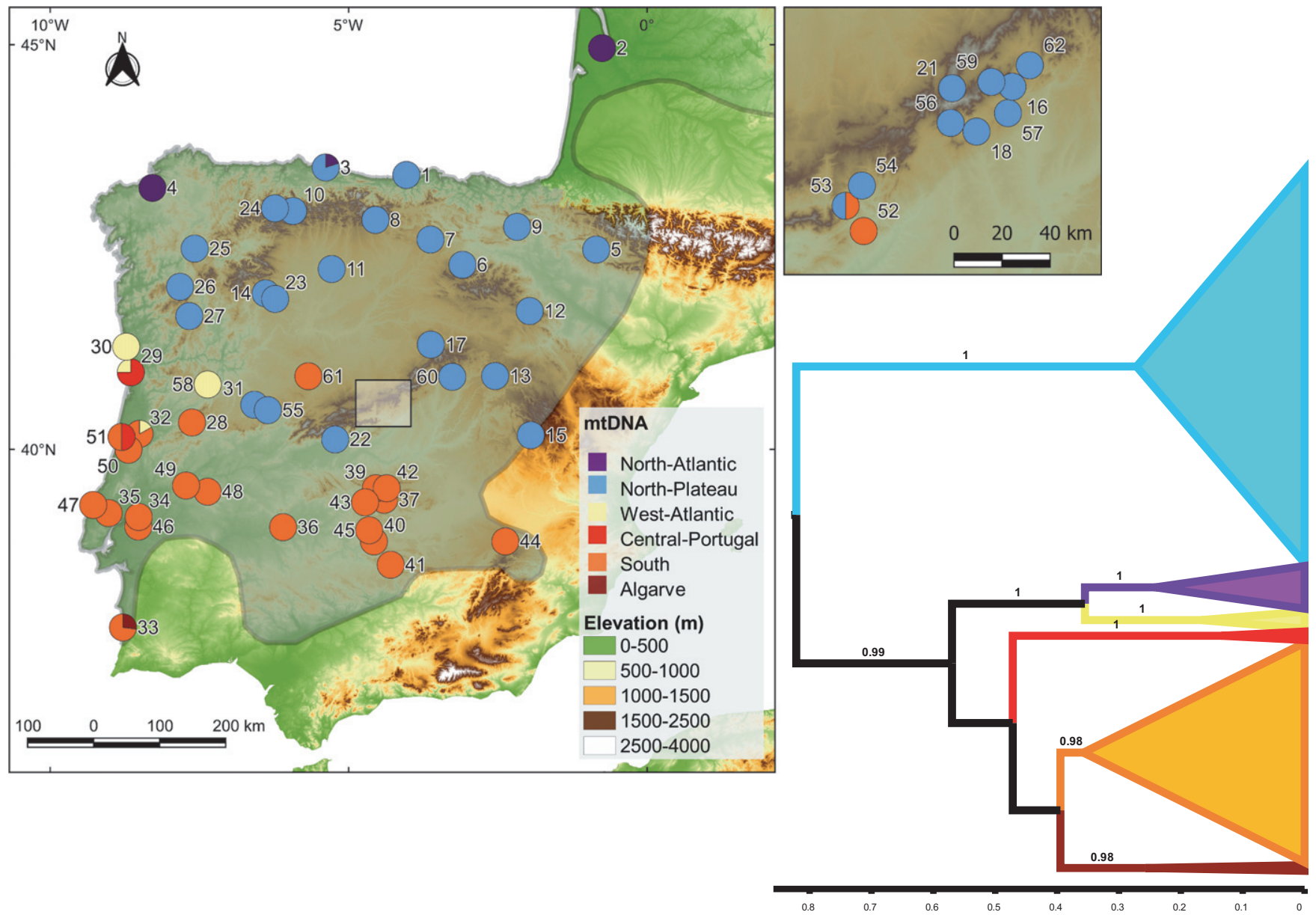

FIGURE 1 Left: map showing the geographical distribution of the six mtDNA haplogroups in Hyla molleri. The range of $H$. molleri is shaded in grey (Iberian Peninsula) and transparent grey (southern France, where the range boundaries in the contact zone with Hyla arborea are not fully characterized). The inset corresponds to the boxed area in central Iberia. Right: tree showing major mtDNA clades recovered in BEAST. Numbers above branches represent Bayesian posterior probabilities. The scale (bottom) is in millions of years

genotypes of individuals from four populations in Central Spain extracted from Sánchez-Montes et al. (2017, see Table 1).

We used GenAlEx 6.5b3 (Peakall \& Smouse, 2006) to calculate mean allelic richness $(A R)$, observed $\left(H_{O}\right)$ and expected heterozygosity $\left(H_{E}\right)$ and the number of private alleles from multilocus genotypes of individuals sampled at each locality. We ran software StRUCtURE 2.3.4 (Pritchard, Stephens, \& Donnelly, 2000), which implements unsupervised Bayesian clustering analyses, to (a) infer the number of genetic clusters $(K)$ best explaining the genetic structure in the range-wide sample and (b) estimate the assignment probability of each individual to each of the inferred clusters. For each value of $K$ from one to ten, we ran ten replicates with correlated allelic frequencies (Falush, Stephens, \& Pritchard, 2003), $100,000-500,000$ generations of burn-in, and $10^{6}$ postburn-in iterations. We assessed the likelihood of different $K$ values explaining the genetic structure in the data with StRUCTURE HARVESTER 0.6.94 (Earl \& vonHoldt, 2012), using both the original (Pritchard et al., 2000) and the $\Delta K$ (Evanno, Regnaut, \& Goudet, 2005) methods. We used CLUMPAK (Kopelman, Mayzel, Jakobsson,
Rosenberg, \& Mayrose, 2015) to summarize the assignment probabilities of each individual and population to each of the inferred clusters.

\section{4 | Climatic favourability model}

To infer climatically favourable areas for $\mathrm{H}$. molleri under current and past climate, we built an SDM based on this species' current distribution. Occurrence data consisted of presence and absence of records on $10 \times 10 \mathrm{~km}^{2}$ grid cells with a Universal Transverse Mercator (UTM) projection (Figure 3), obtained from Loureiro, Carretero, Ferrand, and Paulo (2010) for Portugal, from MAGRAMA (2015) for Spain and from INPN (2018) for France. We considered that all records previously attributed to $\mathrm{H}$. arborea in Portugal and Spain corresponded to $H$. molleri (Carretero, Martínez-Solano, Ayllón, \& Llorente, 2016).

Model predictors were the 19 bioclimatic variables available in the WorldClim 1.4 dataset (Hijmans, Cameron, Parra, Jones, \& Jarvis, 2005) for current climate. These variables had an appropriate 

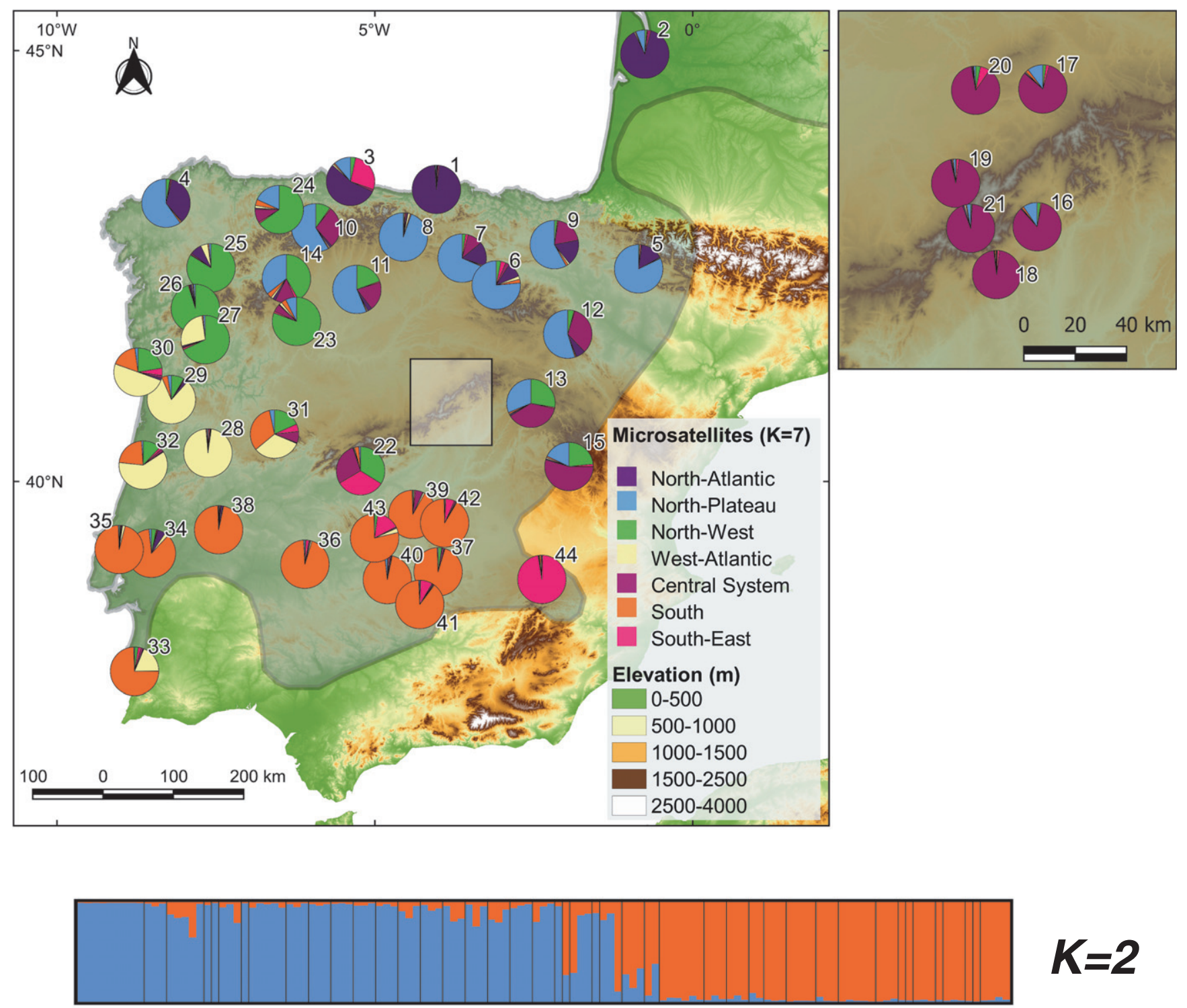

$K=2$
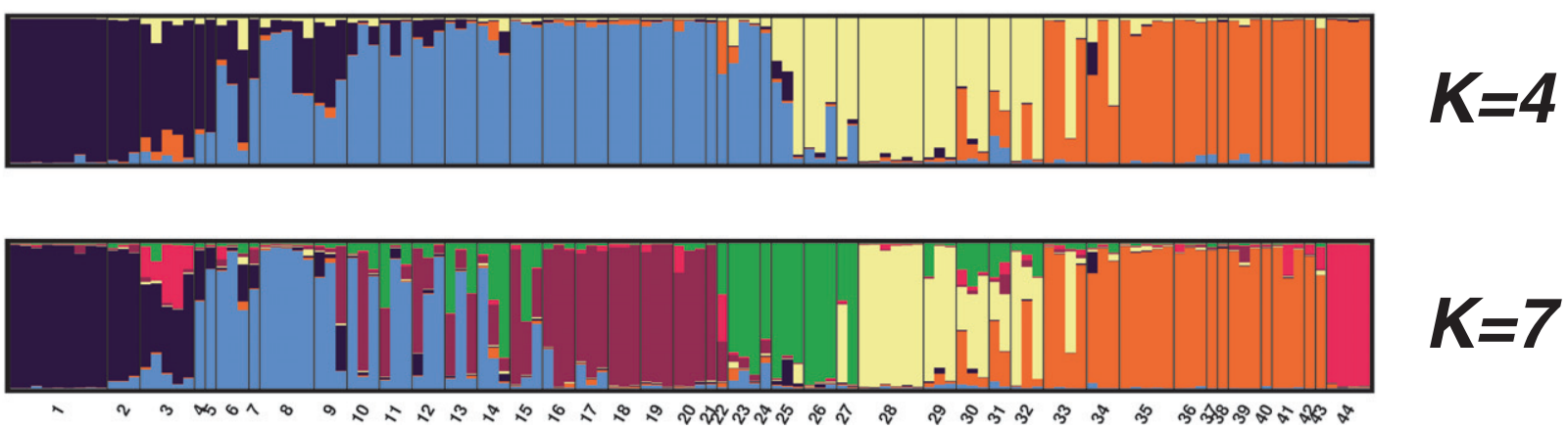

FIGURE 2 Top: map showing the geographical distribution of the seven main clusters recovered in STRUCTURE analyses, with the range of Hyla molleri shaded in grey (Iberian Peninsula) and transparent grey (southern France, where the range boundaries in the contact zone with Hyla arborea are not fully characterized). The inset corresponds to the boxed area in central lberia. Bottom: plot representing the assignment probabilities of each individual from each population (population code numbers in the bottom line) to each inferred cluster for $K=2,4$ and 7

temporal and spatial scale for our study, and have potential direct or indirect relationships with the occurrence of $\mathrm{H}$. molleri (Supporting Information Appendix S3).
To encompass while not overly exceeding the species' distribution range, the study area included the Iberian Peninsula and metropolitan France (Figure 3). Vector maps of countries and of the $10 \times 10 \mathrm{~km}^{2}$ 
Current presence

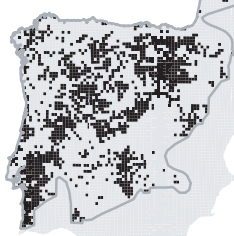

MH favourability (CCSM)

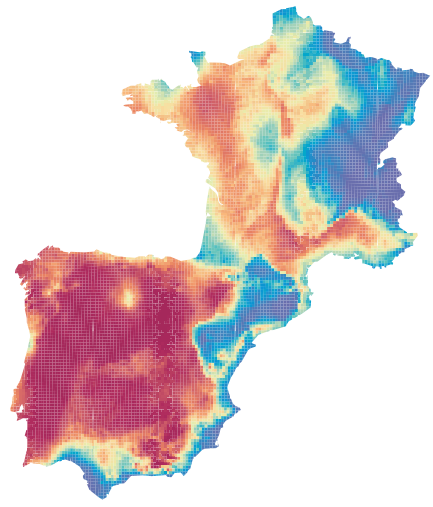

LGM favourability (CCSM)

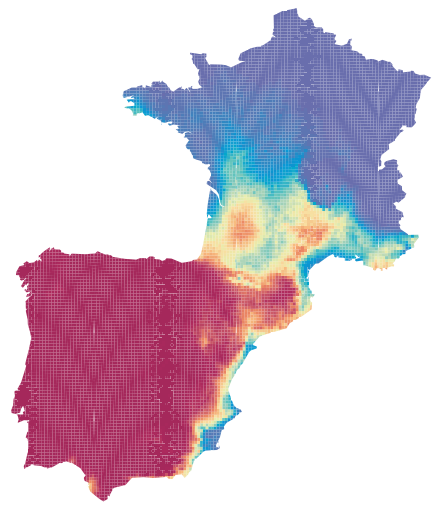

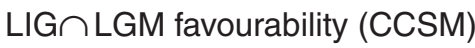

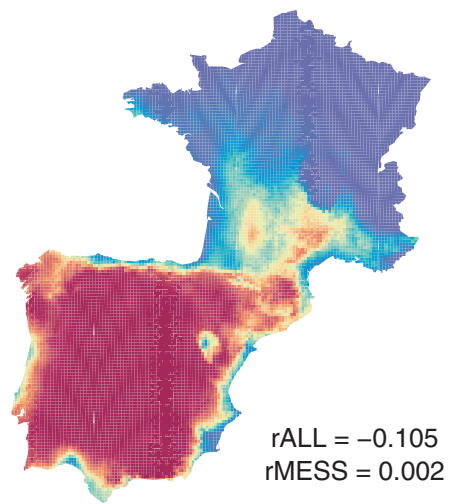

Current favourability

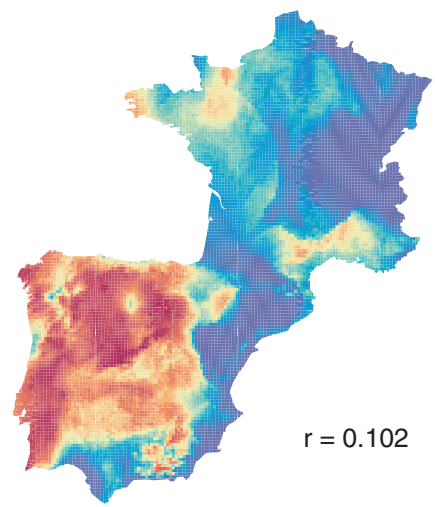

MH favourability (MIROC)

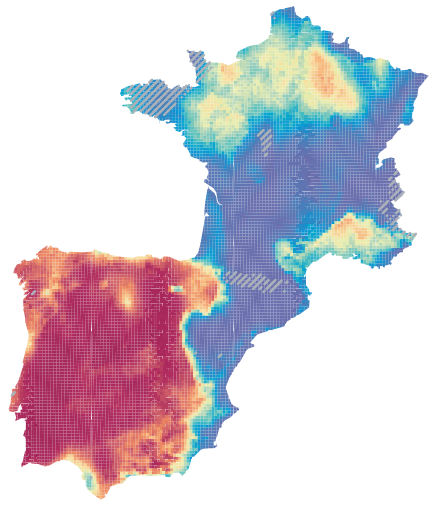

LGM favourability (MIROC)

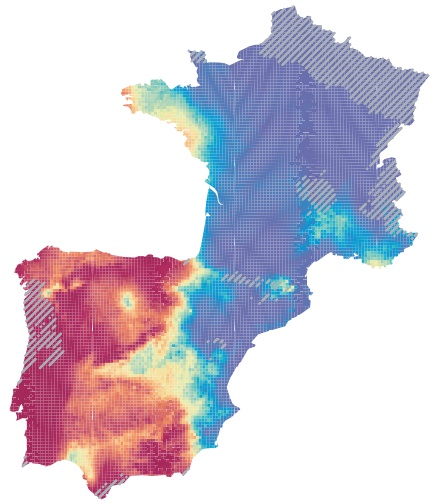

$L I G \cap L G M$ favourability (MIROC)

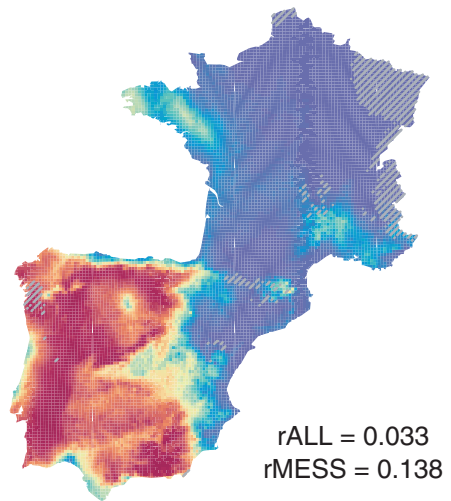

LIG favourability

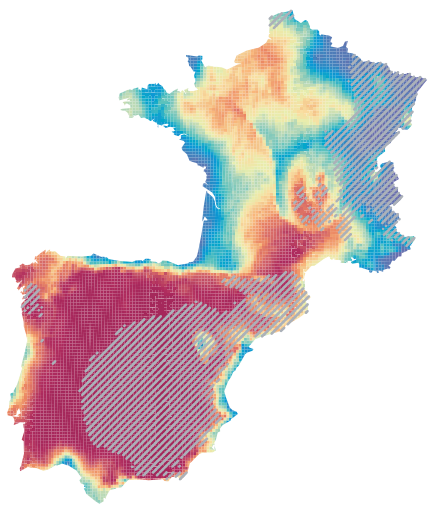

$\mathrm{MH}$ favourability (MPI)

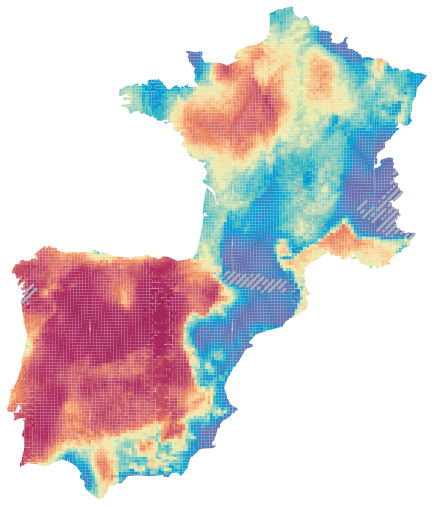

LGM favourability (MPI)

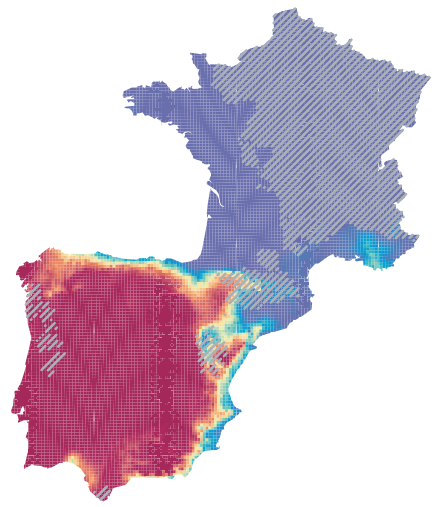

$L I G \cap L G M$ favourability (MPI)

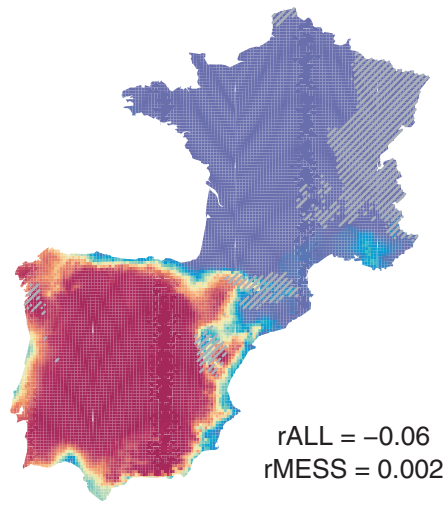


FIGURE 3 Current occurrence records (black $10 \times 10 \mathrm{~km}^{2}$ cells), current distribution range encompassing these records (grey outline) and climatic favourability (colour scale ranging from dark blue-least favourable-through yellow to dark red-most favourable-) for Hyla molleri, in the present and under projected climates for the Last Inter-Glacial (LIG) and for each of three simulations for the Last Glacial Maximum (LGM) and the Mid Holocene (MH): CCSM4, MIROC-ESM and MPI-ESM-P. Predictions in shaded areas are outside climatic conditions accessible to the model (analogous climates) and are therefore less reliable. The correlation $(r)$ between favourability and genetic diversity is shown where applicable (see Section 2)

UTM grids were downloaded from the EDIT geoplatform (Sastre, Roca, \& Lobo, 2009) and clipped to the study area. Species occurrence data from Portugal (Loureiro et al., 2010) and Spain (MAGRAMA, 2015) were imported directly from the source databases. Data from France (INPN, 2018) were geo-referenced and digitized manually from the online source map using QGIS (QGIS Development Team, 2014). We further completed the dataset by adding the locations of our own samples (Table 1). UTM cells that were cut by the coastline or by the limits of UTM zones were excluded from model training, to avoid spurious effects derived from their smaller effective area. The model included 1,321 cells with $H$. molleri presence records, and 12,958 cells without. Repeated occurrence records within the same cell were not considered. At this resolution scale, the dispersal capacity of $H$. molleri is negligible, so we can consider that presence in contiguous cells reflects adequate environment in those cells, and not simply spatial autocorrelation in species occurrence.

The model was built in R v3.0.2 (R Core Team, 2017) with the fuzzYSIM package (Barbosa, 2015a) using the favourability function (Real, Barbosa, \& Vargas, 2006), a generalized linear model that allows obtaining prevalence-independent values directly comparable across taxa and time periods (Acevedo \& Real, 2012). Unlike the generality of other algorithms, which model probability or suitability, favourability can be formally used in fuzzy logical analyses (Acevedo \& Real, 2012; Real et al., 2006), such as the intersections that assess the maintenance of adequate conditions across time periods (see below). Nevertheless, to ensure that the choice of modelling approach did not strongly affect our conclusions, we also modelled the same data with the widely used algorithm Maxent. We built this model with the MAXNET R package, using linear and quadratic features (Merow, Smith, \& Silander, 2013) and a complementary log-log (cloglog) transform (Phillips, Anderson, Dudík, Schapire, \& Blair, 2017). We then mapped these predictions for each climate scenario and measured their correlations with the corresponding favourability predictions.

The selection of variables followed a three-step protocol, as implemented in the 'fuzzySim::multGLM' function: first, variables with a significant bivariate relationship with the distribution of the species were selected based on the false discovery rate (Benjamini \& Hochberg, 1995); the selected variables were included in a multivariate model through a forward-stepwise procedure based on Akaike's Information Criterion (Akaike, 1974); finally, non-significant variables left in the model were removed in a stepwise manner (Crawley, 2007).

Model performance was evaluated with the MODEvA $\mathrm{R}$ package (Barbosa, Real, Muñoz, \& Brown, 2013). We used several performance metrics that measure discrimination, classification (using 0.5 as the threshold value, which for favourability models equates to using prevalence; Real et al., 2006; Acevedo \& Real, 2012), explanatory power and calibration - that is the fit of predicted probabilities to observed occurrence frequencies (see Jiménez-Valverde, Acevedo, Barbosa, Lobo, \& Real, 2013).

The model was then projected towards the past, to hindcast climatically favourable areas based on WorldClim palaeoclimatic simulations - one for the Last Interglacial period (LIG, 120,000-140,000 years ago), and three for the LGM ( 21,000 years ago) and for the Mid Holocene ( $\sim 6,000$ years ago): CCSM4, MIROC-ESM and MPI-ESM-P (Hijmans et al., 2005). We quantified the general changes in favourability between past simulations and current climate, using the fuzzy range change measures (including overall proportional gain, loss and stability) available in 'fuzzySim'. Given that favourability values can be handled directly with fuzzy logic (Acevedo \& Real, 2012; Real et al., 2006), we used the FUZZYSIM package to calculate the fuzzy intersection (Zadeh, 1965) of climatic favourability in the LIG and the LGM, to infer how favourable each cell remained along the glacial cycle.

To avoid the uncertainty caused by extrapolation of models outside the analysed climatic values, we performed a Multivariate Environmental Similarity Surface (MESS) analysis (Elith, Kearney, \& Phillips, 2010), using the MESS function of MODEvA. After excluding dissimilar environments (i.e. UTM cells with negative MESS values), we calculated the correlations between sustained favourability values (LIG-LGM intersections) and current genetic diversity within the distribution range of $\mathrm{H}$. molleri, which was taken from IUCN (2017) and edited to encompass all recorded occurrences (Figure 3). We combined different measures of genetic diversity (allelic richness, observed heterozygosity and number of private alleles; nucleotide diversity was excluded for its smaller sample size) in a principal components analysis (PCA) with R function PRINCOMP, using the correlation (rather than the covariance) matrix as these variables are measured on different scales. We confirmed that the first PCA axis captured most ( 60\%) of the variation and correlated positively with each diversity measure. We then used kriging interpolation (AUTOKRIGE function of the AUTOMAP R package) to estimate genetic diversity across the species' range, averaged it over the UTM $10 \times 10-\mathrm{km}^{2}$ cells, and correlated it with the intersection of current and past climatic favourability.

\section{3 | RESULTS}

\section{1 | Mitochondrial DNA analyses}

Nucleotide diversity is higher in western and central areas within the range of $\mathrm{H}$. molleri (Supporting Information Appendix S3). The mtDNA tree recovered by BEAST contained two well-supported major clades that originated back in the Pleistocene (95\% highest posterior density interval [95\% HPDI] for the root: 0.35-1.36 Myr, median: 
$0.78 \mathrm{Myr}$ ), corresponding to haplotypes found in the Northern Plateau of the Iberian Peninsula (95\% HPDI for the time to the most recent common ancestor [TMRCA]: $0.12-0.46 \mathrm{Myr}$ ) and in the South+Atlantic regions (95\% HPDI TMRCA: 0.24-0.96 Myr) respectively (Figure 1). The composite South+Atlantic clade is further subdivided into five subclades, corresponding to (a) the North-Atlantic localities in Galicia (NW Spain) and Southern France, (b) the AtlanticLusitanian localities in central Portugal (two subclades) and (c) the southern distribution range, including a widespread haplogroup covering most of the Southern Plateau and a geographically restricted clade from the Algarve (S Portugal) (Figure 1). In total, 185 different mtDNA haplotypes were retrieved from the 247 individual sequences, with $\mathrm{H} 8$ as the most common haplotype in the Southern clade (found in five localities) and H90 as the most widespread haplotype within the Northern-Plateau clade (found in eight localities). Localities 2 (Segonnes, France) and 14 (Codesal, Spain) showed the highest haplotype diversity in our sample, with 12 different haplotypes each (Table 1).

Continuous diffusion analyses inferred a geographical location for the root of the mtDNA tree in a broad area in northwestern lberia, south of the Cantabrian mountains and north of the Sistema Central mountains, extending towards the coast of central Portugal. From this ancestral area, populations would have expanded along a SW-NE axis first, followed by eastward expansions north and south of Sistema Central and by an independent expansion north of the Cantabrian mountains, from which populations would have subsequently expanded west and east along the coast (Supporting Information Figure S3.2).

All test statistics showed significant evidence for demographic expansions in $\mathrm{H}$. molleri, as well as for each major mtDNA clade separately (Table 2).

\section{2 | Microsatellite analyses}

Localities in northern Iberian mountains and in western Iberia showed the highest genetic diversity, measured as mean AR and $H_{O}$ (Supporting Information Appendix S3). In contrast, the highest concentration of private alleles occurred at both geographical extremes, in localities of France and southwestern Portugal (Supporting Information Appendix S3).

Clustering analyses yielded $K=4$ and, especially, $K=7$ as the numbers of clusters best explaining the genetic structure in the microsatellite data (Figure 2 and Supporting Information Appendix S2). Four of the groups inferred from mtDNA data (North-Atlantic, NorthPlateau, West-Atlantic and South) were also recovered in microsatellite analyses with $K=4$ (Figure 2). At $K=7$, the Central System and the northwestern localities were differentiated within the North-Plateau group and a South-eastern cluster was differentiated within the Southern group (Figure 2).

\section{3 | Climatic favourability model}

Model predictions (Figure 3) had good overall evaluation measures, with, for example an area under the receiver operating characteristic curve (AUC) of 0.914, which is considered 'excellent' (Swets, 1988), and a McFadden's pseudo- $R^{2}$ of 0.379 , which is well above what is considered 'excellent fit' (McFadden, 1978; Figure 4). Maxent predictions, obtained for comparison, had essentially the same AUC (0.915) as favourability, slightly higher sensitivity at a threshold equalling the species' prevalence, and lower specificity and remaining classification measures. They also provided essentially similar spatial patterns to those of favourability, with which they were highly correlated (Supporting Information Figure S3.3), therefore indicating that our results were robust to the choice of modelling algorithm.

Climatically favourable areas inferred from model projections generally contracted between time periods, from the LIG to the present (Figures 5 and 6). However, favourability generally remained high across the current distribution range of $\mathrm{H}$. molleri (Figure 3 ). Current genetic diversity showed a general increasing trend towards the southwest (Figure 7). There were no meaningful correlations between genetic diversity and environmental favourability along the glacial cycle, whether or not restricting the analysis to environments analogous to those of today (Figure 3).

\section{DISCUSSION}

The combination of comprehensive range-wide sampling and extensive genetic information, including mtDNA sequences and specific microsatellite markers, has shown that the phylogeographic pattern of $\mathrm{H}$. molleri is more complex than expected based on previous studies (Barth et al., 2011; Gvoždík et al., 2015; Moreira, 2012; Stöck et al., 2012). Our results uncovered finer-scale patterns of genetic structure than previous studies, including evidence for two major Pleistocene lineages (Figure 1), and additional geographically structured subdivision within both major groups (Figures 1 and 2). Furthermore, in contrast to thermophilous Mediterranean species, genetic diversity across the range of $\mathrm{H}$. molleri did not follow a decreasing gradient from putative southern refugia. Instead, we found two main genetic reservoirs in central and southern Portugal

\begin{tabular}{lrlllll} 
Haplogroup & $\boldsymbol{n}$ & $\boldsymbol{D}(\mathrm{F} \& \mathrm{~L})$ & $\boldsymbol{F}(\mathrm{F} \& \mathrm{~L})$ & $\boldsymbol{D}(\mathrm{Taj})$ & $\boldsymbol{R}_{\mathbf{2}}(\mathrm{R})$ & $\boldsymbol{F}_{\mathrm{S}}(\mathrm{Fu})$ \\
\hline North-Plateau & 40 & $-3.066^{*}$ & $-3.356^{*}$ & $-2.371^{* *}$ & $0.038^{* * *}$ & $-23.16^{* * *}$ \\
South+Atlantic & 63 & $-3.513^{*}$ & $-3.746^{*}$ & $-2.526^{* * *}$ & $0.027^{* * *}$ & $-26.15^{* * *}$ \\
All & 100 & $-4.024^{*}$ & $-3.684^{*}$ & $-1.819^{*}$ & $0.040^{*}$ & $-32.39^{* * *}$
\end{tabular}

TABLE 2 Results of historical demographic analyses for Hyla molleri

$n=$ sample size (number of sequences); F\&L = Fu \& Li; Taj = Tajima; $R=$ Ramos-Onsins \& Rozas.

${ }^{*} p<0.05 ;{ }^{* *} p<0.01 ;{ }^{* * *} p<0.001$ 


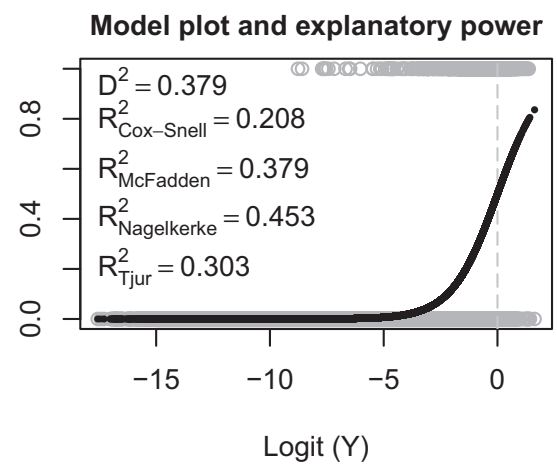

FIGURE 4 Explanatory power, discrimination, classification and calibration performance of the environmental favourability model obtained for current Hyla molleri distribution. $D^{2}, R^{2}$ : different measures of explained deviance. ROC: receiver operating characteristic; AUC: area under the curve. CCR: correct classification rate. TSS (True Skill Statistic) and Cohen's kappa were standardized (s) to vary between 0 and 1 , so that they can be directly compared with the other measures (Barbosa, 2015b). Measures and plots were obtained with the moDEvA R package

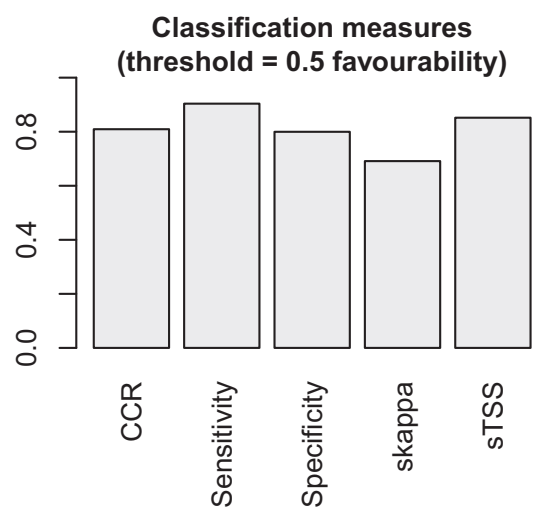

ROC curve (discrimination)

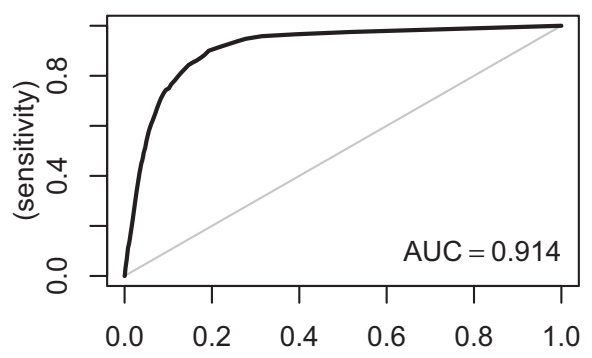

False positive rate

(1-specificity)

Hosmer-Lemeshow goodness-of-fit (deciles)

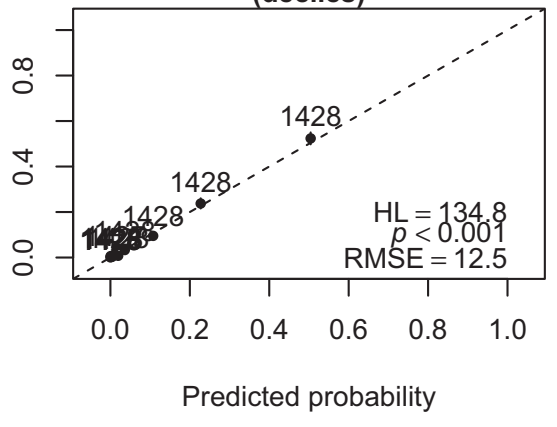

and in northern Spain (North-Plateau). The distribution of genetic diversity in $\mathrm{H}$. molleri, and its lack of correlation with areas that remained climatically favourable through the LIG and LGM towards the present (Figure 3), suggest that this Atlantic species does not accommodate to the Pleistocene history documented in more thermophilous Mediterranean amphibians (Gutiérrez-Rodríguez et al., 2017a, 2017b).

The estimated age of the common ancestor of the two Pleistocene lineages of $\mathrm{H}$. molleri is relatively young ( 780,000 years), especially when compared to other Iberian species like $P$. waltl (Gutiérrez-Rodríguez et al., 2017b), Lissotriton boscai (Martínez-Solano et al., 2006) or Alytes obstetricans (Gonçalves et al., 2015), highlighting their different evolutionary histories. Hyla molleri shares a common ancestor with $\mathrm{H}$. orientalis, an eastern species distributed from Central Europe to the Caspian Sea (Gvoždík et al., 2015). Time estimates for their common ancestor range from middle Pleistocene (Gvoždík et al., 2015) to early Pliocene (Dufresnes et al., 2018; Stöck et al., 2012), much earlier than our TMRCA estimates (Figure 1). The sister relationship between both species, their current disjunct distribution and their different phylogeographic structure suggest a substantial change in the distribution range of $\mathrm{H}$. molleri along the Pleistocene, including a relatively recent colonization (just over $1 \mathrm{Myr}$ ) of the Iberian Peninsula from populations north of the Pyrenees, where the species could have been widely distributed. These northern populations would have disappeared during some of the Pleistocene glacial maxima, remaining only those in the Iberian refugium, which are putatively represented by fossil remains dating back to the middle Pleistocene in the North Plateau in Atapuerca, Burgos (1.4-1.2 Myr; Cuenca-Bescós et al., 2010).

In view of this evolutionary history, $H$. molleri would fit a type ' $R$ ' model (Recuero \& García-París, 2011), in which current genetic diversity originated in populations surviving in true Pleistocene glacial refugia, whereas older lineages became extinct during the Pleistocene. Similarly shallow patterns of phylogeographic structure have been observed in a number of largely co-distributed species, including both Atlantic species like Lissotriton helveticus (Recuero \& GarcíaParís, 2011), Discoglossus galganoi (Martínez-Solano, 2004) and Rana iberica (Teixeira, Gonçalves, Ferrand, García-París, \& Recuero, 2018), and Mediterranean taxa like Alytes cisternasii (Gonçalves et al., 2009) or P. cultripes (Gutiérrez-Rodríguez et al., 2017a). Unfortunately, for several of these taxa we lack detailed information regarding the relationship between changes in climatic favourability and patterns of genetic diversity. The only model ' $R$ ' species for which this integrative approach combining genetic information and SDM has been applied so far showed a clear signature of range contraction during the LGM, followed by continuous expansion during the Holocene, in line with the classical model (Gutiérrez-Rodríguez et al., 2017a).

Ancestral lineages of $\mathrm{H}$. molleri north of the Pyrenees were probably extirpated by extreme climatic changes, but the cold-tolerance of the species possibly facilitated demographic stability through the milder climate fluctuations in the Iberian refugium, taking advantage of the habitat heterogeneity provided by topography in this region (Abellán \& Svenning, 2014; Gomez \& Lunt, 2007). Topography may have also played a fundamental role in shaping the observed phylogeographic pattern. For instance, recolonization of the area along the Cantabrian coast in northern Spain up to Atlantic France took place from populations in NW Iberia (Supporting Information Figure S3.2), whereas the geographically closer Northern Plateau clade barely expanded north of the Cantabrian mountains, which were covered by large ice sheets during Pleistocene glacial maxima (Hewitt, 1996). A similar pattern of historical isolation mediated by a 
LIG to LGM (CCSM)
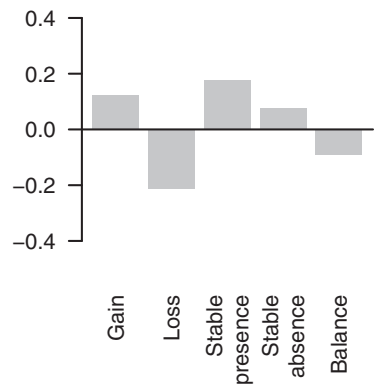

LGM to MH (CCSM)
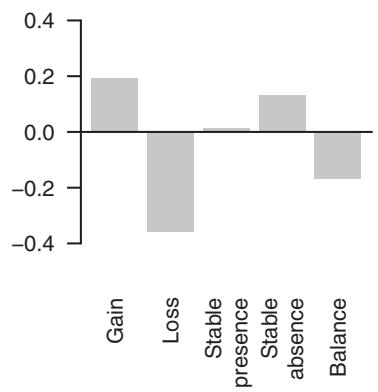

MH to present (CCSM)
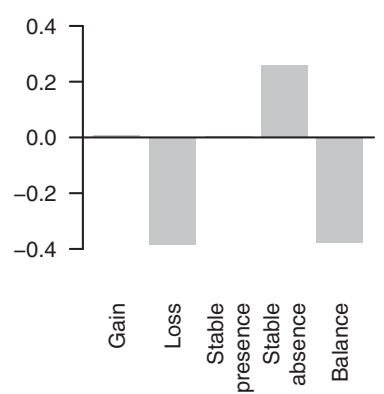

LIG to LGM (MIROC)

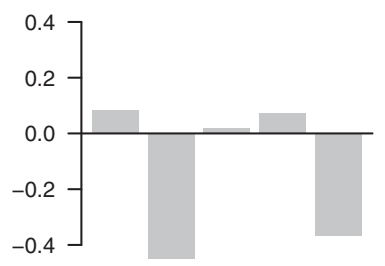

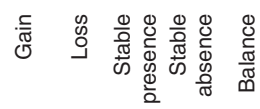

LGM to MH (MIROC)

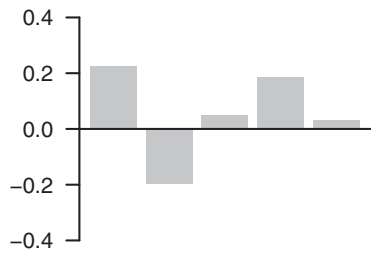

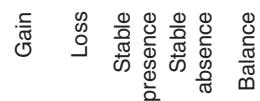

MH to present (MIROC)

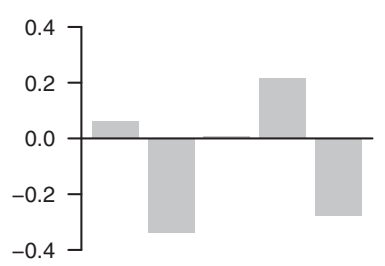

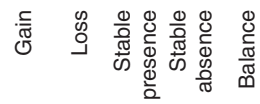

LIG to LGM (MPI)

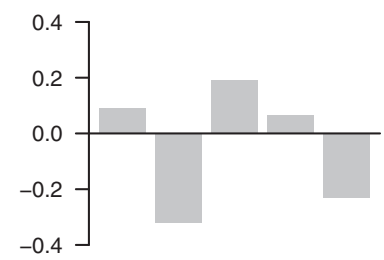

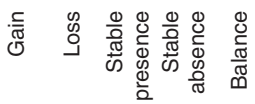

LGM to MH (MPI)

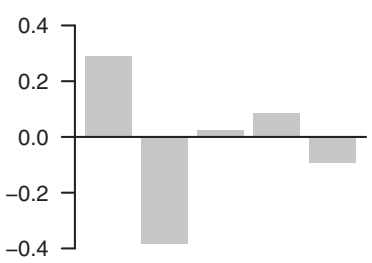

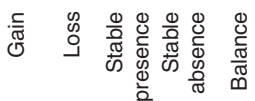

MH to present (MPI)

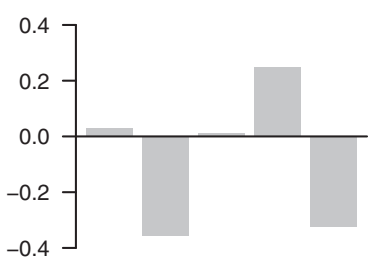

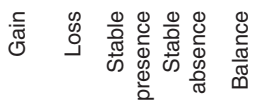

FIGURE 5 Fuzzy range change measures (fuzzy equivalents of the proportional gain, loss and overall change in areas climatically favourable for the presence of Hyla molleri) among time periods, from the Last Inter-Glacial (LIG) to the LGM, the Mid-Holocene (MH) and the present, including the three paleoclimatic simulations currently available across periods on WorldClim (CCSM4, MIROCESM and MPI-ESM-P) mountain barrier can explain the differentiation between the South and North-Plateau lineages, which are currently in contact along the Sistema Central mountains. The role of mountains as barriers to dispersal would have been stronger during glacial maxima, whereas in the present interglacial neither the Cantabrian nor the Sistema Central mountains act as impermeable barriers (Domínguez-Villar et al., 2013; Sánchez-Montes et al., 2018), and populations of $H$. molleri occur all along the altitudinal gradient up to elevations above the treeline $>2,000 \mathrm{~m}$ a.s.l. (Martínez-Solano, 2006). Climatic conditions during the LGM must have prevented colonization of alpine habitats until the Holocene, when lineage admixture would be limited by demographic processes according to the 'founder takes all' model (Waters, Fraser, \& Hewitt, 2013).

According to our model, the Iberian Peninsula experienced a progressive and continuous decrease in climatically favourable areas for $H$. molleri since the LIG, especially in southern and eastern Iberia, where the species is currently absent (Figure 3). At the only two localities with upper Pleistocene-Holocene $H$. molleri fossils (Blain \& Corchón Rodríguez, 2018; Cuenca-Bescós et al., 2010), climatic favourability generally remained high during the analysed timeframe (Supporting Information Figure S3.4). This provides support to our model, even if with limited data. Interestingly, we found a good match between climatically favourable areas through time and those areas where $H$. molleri currently occurs (Figure 3 ), which may explain the absence of a positive correlation between historical climatic favourability and current patterns of genetic diversity. According to this interpretation, climatic changes in the late Pleistocene would not have led to strong extinction/recolonization dynamics in $\mathrm{H}$. $\mathrm{mol}-$ leri, at least not as severe as in other less vagile, more thermophilous, co-distributed amphibian species, for which these extinction/recolonization dynamics have been invoked to explain correlations between sustained climatic favourability and genetic diversity (Gutiérrez-Rodríguez et al., 2017a, 2017b). Instead, the historical biogeography of $H$. molleri may have been mainly characterized by resilience against climatic fluctuations based on its cold-tolerance, its dispersal capacity, and its preference for more stable (in terms of hydroperiod predictability) breeding sites, as compared to other Iberian species such as P. waltl, P. cultripes, Epidalea calamita or Pelophylax perezi (Sánchez-Montes et al., 2018). Therefore, climatic changes would have only affected areas in the periphery of its Iberian range. Signatures of demographic expansion based on mtDNA sequences (Table 2) may represent the recolonization of new areas that became 
Box plots of favourability
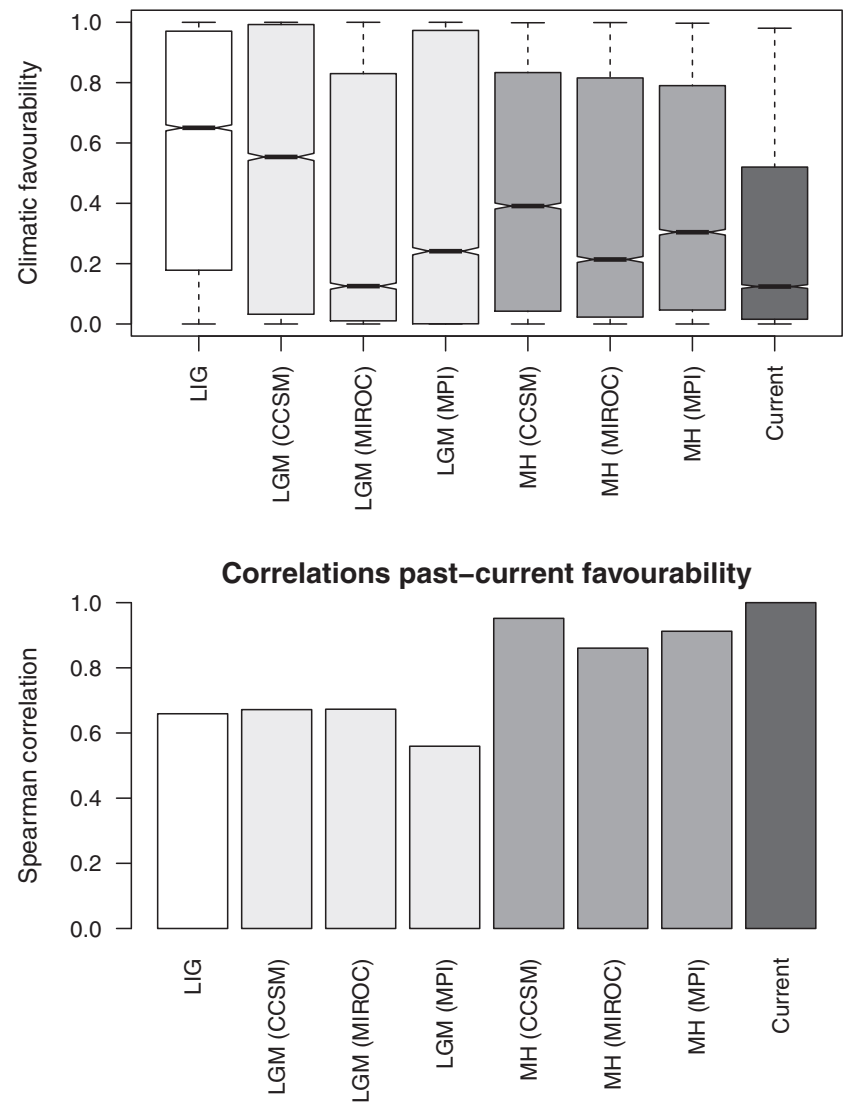

FIGURE 6 Climatic favourability values for Hyla molleri across the study area (box plots showing median, upper and lower quartiles and extreme values) in the Last Inter-Glacial (LIG), the LGM, the Mid Holocene $(\mathrm{MH})$ and the present, under the three paleoclimatic simulations currently available across periods on WorldClim (CCSM4, MIROC-ESM and MPI-ESM-P) and their correlation with current climatic favourability

briefly favourable during the Mid Holocene, although favourability in these areas declined again towards the present (Figure 3), causing extinctions in recent times (Supporting Information Figure S1.2). The high dispersal capacity of this species would help it track climatic changes with rapid demographic responses (e.g. latitudinal/altitudinal migrations), explaining the lack of correlation between genetic diversity and climatic stability.

Our results suggest that the biogeographic history of $\mathrm{H}$. molleri since the Pleistocene has been characterized by a relatively stable climatic favourability in the core of the species distribution within the Iberian refugium, with demographic resilience to climate changes and a decrease in favourability affecting only peripheral populations. This contrasts with the large-scale cycles of extinctionrecolonization inferred for other more thermophilous, co-distributed amphibian species in Iberia, providing new insights about the evolutionary history of amphibian assemblages. Cold-tolerance might have buffered the effect of Pleistocene climatic fluctuations on the demographic history of southern Atlantic species within their glacial refugia, thus preventing strong genetic diversity depletions as experienced by thermophilous species. Also, dispersal ability probably

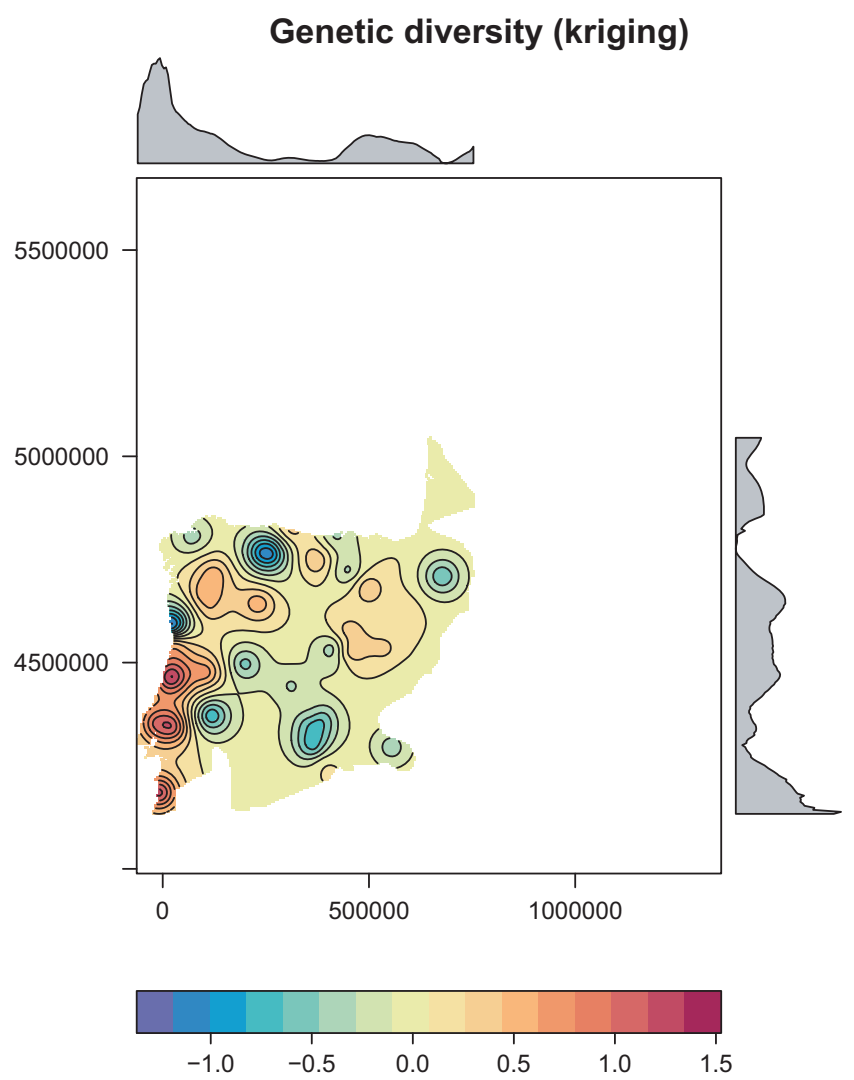

FIGURE 7 Spatial trends in current genetic diversity of Hyla molleri across its distribution range, based on kriging interpolation of the first axis of a principal components analysis of observed heterozygosity, allelic richness and number of private alleles

played an important role in the capacity of species to respond to fluctuations in favourability through time. These two traits drove the resilience of $\mathrm{H}$. molleri through the climatic cycles of the Pleistocene, and this inference could be used to model the response of this and other cold-tolerant species to current forecasts of global warming. These results can be applied to the conservation of the evolutionary potential of $\mathrm{H}$. molleri, which would be dependent on the maintenance of the differentiated gene pools identified along environmental gradients, representing this species' ecological breadth.

\section{ACKNOWLEDGEMENTS}

We thank G. Alarcos, D. Álvarez, J. Álvarez, J.W. Arntzen, J. Barbadillo, A. Bermejo, D. Buckley, M. García París, A. Gosá, C. Grande, J. Gutiérrez, P. Hernández, E. Jockusch, M. Lapeña, R. Pereira, J. A. Saz, P. Segurado and F. Smith for help collecting samples and M. J. Fernández Benéitez for assistance in the laboratory. Isabel Rey and Beatriz Álvarez (MNCN DNA and Tissue collection) provided access to samples under their care. H.A. Blain and J. Bisbal-Chinesta provided helpful comments on the fossil record of $H$. molleri. This research was funded by grants CGL2008-04271-C02-01/BOS and 
CGL2011-28300 (Ministerio de Ciencia e Innovación, Ministerio de Economía y Competitividad, Spain and FEDER) to I.M.S., who was supported by funding from the Spanish Ramón y Cajal (RYC-200701668) and Severo Ochoa (SEV-2012-0262) programmes. A.M.B. was supported by the Portuguese "Investigador FCT" programme through contract and exploratory project IF/00266/2013/CP1168/ CT0001.

\section{ORCID}

Gregorio Sánchez-Montes (iD https://orcid.org/0000-0001-8100-1061 A. Márcia Barbosa (D https://orcid.org/0000-0001-8972-7713 Íñigo Martínez-Solano iD http://orcid.org/0000-0002-2260-226X

\section{REFERENCES}

Abellán, P., \& Svenning, J.-C. (2014). Refugia within refugia - Patterns in endemism and genetic divergence are linked to Late Quaternary climate stability in the Iberian Peninsula. Biological Journal of the Linnean Society, 113, 13-28. https://doi.org/10.1111/bij.12309

Acevedo, P., \& Real, R. (2012). Favourability: Concept, distinctive characteristics and potential usefulness. Naturwissenschaften, 99, 515-522. https://doi.org/10.1007/s00114-012-0926-0

Akaike, H. (1974). A new look at the statistical model identification. IEEE Transactions on Automatic Control, 19, 716-723. https://doi.org/10. 1109/TAC.1974.1100705

Bandelt, H.-J., Forster, P., \& Röhl, A. (1999). Median-joining networks for inferring intraspecific phylogenies. Molecular Biology and Evolution, 16, 37-48. https://doi.org/10.1093/oxfordjournals.molbev.a 026036

Barbosa, A. M. (2015a). fuzzySim: Applying fuzzy logic to binary similarity indices in ecology. Methods in Ecology and Evolution, 6, 853-858. https://doi.org/10.1111/2041-210X.12372

Barbosa, A. M. (2015b). Re-scaling of model evaluation measures to allow direct comparison of their values. Journal of Brief Ideas. https://doi. org/10.5281/zenodo.15487

Barbosa, A. M., Real, R., Muñoz, A.-R., \& Brown, J. A. (2013). New measures for assessing model equilibrium and prediction mismatch in species distribution models. Diversity and Distributions, 19, 13331338. https://doi.org/10.1111/ddi.12100

Barth, A., Galán, P., Donaire, D., González de la Vega, J. P., Pabijan, M., \& Vences, M. (2011). Mitochondrial uniformity in populations of the treefrog Hyla molleri across the Iberian Peninsula. Amphibia-Reptilia, 32, 557-564.

Benjamini, Y., \& Hochberg, Y. (1995). Controlling the false discovery rate: A practical and powerful approach to multiple testing. Journal of the Royal Statistical Society Series B, 57, 289-300.

Bielejec, F., Rambaut, A., Suchard, M. A., \& Lemey, P. (2011). SPREAD: Spatial phylogenetic reconstruction of evolutionary dynamics. Bioinformatics, 27, 2910-2912. https://doi.org/10.1093/bioinformatics/ btr481

Blain, H.-A., \& Corchón Rodríguez, M. S. (2018). Anfibios y escamosos del Solutrense y Magdaleniense (Pleistoceno Superior Final) de la cueva de Las Caldas (Oviedo, Asturias). In M. S. Corchón Rodríguez (Ed.), La cueva de Caldas (Priorio, Oviedo). Ocupaciones magdalenienses en el valle del Nalón (pp. 209-220). Salamanca, España: Universidad de Salamanca

Buckley, D. (2009). Toward an organismal, integrative, and iterative phylogeography. BioEssays, 31, 784-793. https://doi.org/10.1002/(ISSN) 1521-1878
Canestrelli, D., \& Nascetti, G. (2008). Phylogeography of the pool frog Rana (Pelophylax) lessonae in the Italian peninsula and Sicily: Multiple refugia, glacial expansions and nuclear-mitochondrial discordance. Journal of Biogeography, 35, 1923-1936. https://doi.org/10.1111/j. 1365-2699.2008.01946.x

Carretero, M. A., Martínez-Solano, I., Ayllón, E., \& Llorente, G. A. (2016). Lista patrón de los anfibios y reptiles de España (actualizada a diciembre de 2016). Asociación Herpetológica Española.

Carvalho, S. B., Velo-Antón, G., Tarroso, P., Portela, A. P., Barata, M., Carranza, S., ... Possingham, H. P. (2017). Spatial conservation prioritization of biodiversity spanning the evolutionary continuum. Nature Ecology and Evolution, 1, 0151. https://doi.org/10.1038/s41559-017-0151

Crawley, M. J. (2007). The R book. Chinchester, UK: Wiley. https://doi. org/10.1002/9780470515075

Cuenca-Bescós, G., Rofes, J., López-García, J. M., Blain, H.-A., De Marfá, R. J., Galindo-Pellicena, M. A., ... Carbonell, E. (2010). Biochronology of Spanish Quaternary small vertebrate faunas. Quaternary International, 212, 109-119. https://doi.org/10.1016/j.quaint.2009.06.007

Darriba, D., Taboada, G. L., Doallo, R., \& Posada, D. (2012). jModelTest 2: More models, new heuristics and parallel computing. Nature Methods, 9, 772. https://doi.org/10.1038/nmeth.2109

Domínguez-Villar, D., Carrasco, R. M., Pedraza, J., Cheng, H., Edwards, R. L., \& Willenbring, J. K. (2013). Early maximum extent of paleoglaciers from Mediterranean mountains during the last glaciation. Scientific Reports, 3, 2034. https://doi.org/10.1038/srep02034

Drummond, A. J., Rambaut, A., Shapiro, B., \& Pybus, O. G. (2005). Bayesian coalescent inference of past population dynamics from molecular sequences. Molecular Biology and Evolution, 22, 1185-1192. https://d oi.org/10.1093/molbev/msi103

Dufresnes, C., Mazepa, G., Rodrigues, N., Brelsford, A., Litvinchuk, S. N., Sermier, R, ... Jeffries, D. L. (2018). Genomic evidence for cryptic speciation in tree frogs from the Apennine Peninsula, with description of Hyla perrini sp. nov. Frontiers in Ecology and Evolution, 6, 144. https://doi.org/10.3389/fevo.2018.00144

Dufresnes, C., Wassef, J., Ghali, K., Brelsford, A., Stöck, M., Lymberakis, P., ... Perrin, N. (2013). Conservation phylogeography: Does historical diversity contribute to regional vulnerability in European tree frogs (Hyla arborea)? Molecular Ecology, 22, 5669-5684. https://doi.org/10. $1111 /$ mec.12513

Earl, D. A., \& vonHoldt, B. M. (2012). STRUCTURE HARVESTER: A website and program for visualizing STRUCTURE output and implementing the Evanno method. Conservation Genetics Resources, 4, 359-361. https://doi.org/10.1007/s12686-011-9548-7

Elith, J., Kearney, M., \& Phillips, S. (2010). The art of modelling rangeshifting species. Methods in Ecology and Evolution, 1, 330-342. https://doi.org/10.1111/j.2041-210X.2010.00036.x

Elith, J., \& Leathwick, J. R. (2009). Species distribution models: Ecological explanation and prediction across space and time. Annual Review of Ecology, Evolution, and Systematics, 40, 677-697. https://doi.org/10. 1146/annurev.ecolsys.110308.120159

Evanno, G., Regnaut, S., \& Goudet, J. (2005). Detecting the number of clusters of individuals using the software STRUCTURE: A simulation study. Molecular Ecology, 14, 2611-2620. https://doi.org/10.1111/j. 1365-294X.2005.02553.x

Falush, D., Stephens, M., \& Pritchard, J. K. (2003). Inference of population structure using multilocus genotype data: Linked loci and correlated allele frequencies. Genetics, 164, 1567-1587.

Fu, Y.-X. (1997). Statistical tests of neutrality of mutations against population growth, hitchhiking and background selection. Genetics, 147, 915-925.

Fu, Y.-X., \& Li, W.-H. (1993). Statistical tests of neutrality of mutations. Genetics, 133, 693-709.

Gomez, A., \& Lunt, D. H. (2007). Refugia within refugia: Patterns of phylogeographic concordance in the Iberian Peninsula. In S. Weiss, \& N. Ferrand (Eds.), Phylogeography of Southern European Refugia (pp. 155- 
188). The Netherlands: Springer. https://doi.org/10.1007/1-40204904-8

Gonçalves, H., Maia-Carvalho, B., Sousa-Neves, T., García-París, M., Sequeira, F., Ferrand, N., \& Martínez-Solano, I. (2015). Multilocus phylogeography of the common midwife toad, Alytes obstetricans (Anura, Alytidae): Contrasting patterns of lineage diversification and genetic structure in the Iberian refugium. Molecular Phylogenetics and Evolution, 93, 363-379. https://doi.org/10.1016/j.ympev.2015.08. 009

Gonçalves, H., Martínez-Solano, I., Pereira, R. J., Carvalho, B., GarcíaParís, M., \& Ferrand, N. (2009). High levels of population subdivision in a morphologically conserved Mediterranean toad (Alytes cisternasii) result from recent, multiple refugia: Evidence from mtDNA, microsatellites and nuclear genealogies. Molecular Ecology, 18, 5143-5160. https://doi.org/10.1111/j.1365-294X.2009. 04426.x

Gutiérrez-Rodríguez, J., Barbosa, A. M., \& Martínez-Solano, I. (2017a). Present and past climatic effects on the current distribution and genetic diversity of the Iberian spadefoot toad (Pelobates cultripes): An integrative approach. Journal of Biogeography, 44, 245-258. https://doi.org/10.1111/jbi.12791

Gutiérrez-Rodríguez, J., Barbosa, A. M., \& Martínez-Solano, I. (2017b). Integrative inference of population history in the Ibero-Maghrebian endemic Pleurodeles waltl (Salamandridae). Molecular Phylogenetics and Evolution, 112, 122-137. https://doi.org/10.1016/j.ympev.2017.04. 022

Gvoždík, V., Canestrelli, D., García-París, M., Moravec, J., Nascetti, G., Recuero, E., ... Kotlík, P. (2015). Speciation history and widespread introgression in the European short-call tree frogs (Hyla arborea sensu lato, $\mathrm{H}$. intermedia and $\mathrm{H}$. sarda). Molecular Phylogenetics and Evolution, 83, 143-155.

Heled, J., \& Drummond, A. J. (2010). Bayesian inference of species trees from multilocus data. Molecular Biology and Evolution, 27, 570-580. https://doi.org/10.1093/molbev/msp274

Hewitt, G. M. (1996). Some genetic consequences of ice ages, and their role in divergence and speciation. Biological Journal of the Linnaean Society, 58, 247-276. https://doi.org/10.1111/j.1095-8312.1996.tb 01434.x

Hijmans, R. J., Cameron, S. E., Parra, J. L., Jones, P. G., \& Jarvis, A. (2005). Very high resolution interpolated climate surfaces for global land areas. International Journal of Climatology, 25, 1965-1978. https://doi.org/10.1002/(ISSN)1097-0088

INPN. (2018). Inventaire National du Patrimoine Naturel. Retrieved from https://inpn.mnhn.fr/espece/cd_nom/774683.

IUCN. (2017). The IUCN red list of threatened species. Retrieved from http://www.iucnredlist.org (accessed 14 December 2017)

Jiménez-Valverde, A., Acevedo, P., Barbosa, A. M., Lobo, J. M., \& Real, R. (2013). Discrimination capacity in species distribution models depends on the representativeness of the environmental domain. Global Ecology and Biogeography, 22, 508-516. https://doi.org/10.1111/ geb.12007

Kopelman, N. M., Mayzel, J., Jakobsson, M., Rosenberg, N. A., \& Mayrose, I. (2015). ClumpaK: A program for identifying clustering modes and packaging population structure inferences across K. Molecular Ecology Resources, 15, 1179-1191. https://doi.org/10.1111/17550998.12387

Lanfear, R., Calcott, B., Ho, S. Y. W., \& Guindon, S. (2012). PartitionFinder: Combined selection of partitioning schemes and substitution models for phylogenetic analyses. Molecular Biology and Evolution, 29, 1695-1701. https://doi.org/10.1093/molbev/mss020

Leigh, J. W., \& Bryant, D. (2015). POPART: Full-feature software for haplotype network construction. Methods in Ecology and Evolution, 6, 1110-1116. https://doi.org/10.1111/2041-210X.12410

Llusia, D., Márquez, R., Beltrán, J. F., Benítez, M., \& do Amaral, J. P. (2013). Calling behaviour under climate change: Geographical and seasonal variation of calling temperatures in ectotherms. Global Change Biology, 19, 2655-2674. https://doi.org/10.1111/gcb.12267

Lobo, J. M., Martínez-Solano, I., \& Sanchiz, B. (2016). A review of the palaeoclimatic inference potential of Iberian Quaternary fossil batrachians. Palaeobiodiversity and Palaeoenvironments, 96, 125-148. https://doi.org/10.1007/s12549-015-0224-x

Loureiro, A., Carretero, M. A., Ferrand, N., \& Paulo, O. S. (2010). Atlas dos Anfibios e répteis de Portugal continental. Lisbon, Portugal: Esfera do Caos.

MAGRAMA. (2015). Inventario español de especies terrestres. Fauna de vertebrados: anfibios y reptiles. Ministerio de Agricultura, Alimentación y Medio Ambiente. Retrieved from http://www.mapa ma.gob.es/es/biodiversidad/temas/inventarios-nacionales/inventarioespecies-terrestres/inventario-nacional-de-biodiversidad/bdn-ieetdefault.aspx

Martínez-Solano, I. (2004). Phylogeography of Iberian Discoglossus (Anura: Discoglossidae). Journal of Zoological Systematics and Evolutionary Research, 42, 298-305. https://doi.org/10.1111/j.1439-0469.2004. 00257.x

Martínez-Solano, I. (2006). Atlas de distribución y estado de conservación de los anfibios de la Comunidad de Madrid. Graellsia, 62, 253-291. https://doi.org/10.3989/graellsia.2006.v62.iExtra.121

Martínez-Solano, I., Teixeira, J., Buckley, D., \& García-París, M. (2006). Mitochondrial DNA phylogeography of Lissotriton boscai (Caudata, Salamandridae): Evidence for old, multiple refugia in an Iberian endemic. Molecular Ecology, 15, 3375-3388. https://doi.org/10.1111/j. 1365-294X.2006.03013.x

McFadden, D. (1978). Cost, revenue, and profit functions. History of economic thought chapters. Production economics: a dual approach to theory and applications. M. Fuss \& D. McFadden (Eds.). McMaster University Archive for the History of Economic Thought.

Merow, C., Smith, M. J., \& Silander, J. A. Jr (2013). A practical guide to MaxEnt for modeling species' distributions: What it does, and why inputs and settings matter. Ecography, 36, 1058-1069. https://doi. org/10.1111/j.1600-0587.2013.07872.x

Moreira, C. N. (2012). Population analysis of Hyla arborea and Hyla meridionalis (Amphibia, Anura) in Portugal: A molecular genetic and bioacoustic approach. Universidade de Lisboa, Portugal.

Peakall, R., \& Smouse, P. E. (2006). GENALEX 6: Genetic analysis in Excel. Population genetic software for teaching and research. Molecular Ecology Notes, 6, 288-295. https://doi.org/10.1111/j.1471-8286. 2005.01155.x

Phillips, S. J., Anderson, R. P., Dudík, M., Schapire, R. E., \& Blair, M. E. (2017). Opening the black box: An open-source release of Maxent. Ecography, 40, 887-893. https://doi.org/10.1111/ecog.03049

Pritchard, J., Stephens, M., \& Donnelly, P. (2000). Inference of population structure using multilocus genotype data. Genetics, 155, 945959.

QGIS Development Team. (2014). QGIS Geographic Information System. Vancouver, Canada: Open Source Geospatial Foundation. Retrieved from http://qgis.org

R Core Team. (2017). R: A language and environment for statistical computing. Vienna, Austria: R Foundation for Statistical Computing.

Rambaut, A., Drummond, A. J., Xie, D., Baele, G., \& Suchard, M. A. (2018). Posterior summarisation in Bayesian phylogenetics using Tracer 1.7. Systematic Biology, 67, 901-904. https://doi.org/10.1093/ sysbio/syy032

Ramos-Onsins, S. E., \& Rozas, J. (2002). Statistical properties of new neutrality tests against population growth. Molecular Biology and Evolution, 19, 2092-2100. https://doi.org/10.1093/oxfordjournals.molbe v.a004034

Real, R., Barbosa, A. M., \& Vargas, J. M. (2006). Obtaining environmental favourability functions from logistic regression. Environmental and Ecological Statistics, 13, 237-245. https://doi.org/10.1007/s10651005-0003-3 
Recuero, E., \& García-París, M. (2011). Evolutionary history of Lissotriton helveticus: Multilocus assessment of ancestral vs. recent colonization of the Iberian Peninsula. Molecular Phylogenetics and Evolution, 60, 170-182. https://doi.org/10.1016/j.ympev.2011.04.006

Reino, L., Ferreira, M., Martínez-Solano, I., Segurado, P., Xu, C., \& Barbosa, A. M. (2017). Favourable areas for co-occurrence of parapatric species: Niche conservatism and niche divergence in Iberian tree frogs and midwife toads. Journal of Biogeography, 44, 88-98. https://doi.org/10.1111/jbi.12850

Rozas, J., Ferrer-Mata, A., Sánchez-DelBarrio, J. C., Guirao-Rico, S., Librado, P., Ramos-Onsins, S. E., \& Sánchez-Gracia, A. (2017). DnaSP 6: DNA sequence polymorphism analysis of large data sets. Molecular Biology and Evolution, 34, 3299-3302. https://doi.org/10.1093/molbe $\mathrm{v} / \mathrm{msx} 248$

Sánchez-Montes, G., Ariño, A. H., Vizmanos, J. L., Wang, J., \& MartínezSolano, I. (2017). Effects of sample size and full sibs on genetic diversity characterization: A case study of three syntopic Iberian pond-breeding amphibians. Journal of Heredity, 108, 535-543. https://doi.org/10.1093/jhered/esx038

Sánchez-Montes, G., Recuero, E., Gutiérrez-Rodríguez, J., Gomez-Mestre, I., \& Martínez-Solano, I. (2016). Species assignment in the Pelophylax ridibundus $x P$. perezi hybridogenetic complex based on 16 newly characterised microsatellite markers. Herpetological Journal, 26, 99108.

Sánchez-Montes, G., Wang, J., Ariño, A. H., \& Martínez-Solano, Í. (2018). Mountains as barriers to gene flow in amphibians: Quantifying the differential effect of a major mountain ridge on the genetic structure of four sympatric species with different life history traits. Journal of Biogeography, 45, 318-331. https://doi.org/10.1111/jbi. 13132

Sastre, P., Roca, P., \& Lobo, J. M. (2009). A Geoplatform for improving accessibility to environmental cartography. Journal of Biogeography, 36, 568. https://doi.org/10.1111/j.1365-2699.2008.02070.x

Stöck, M., Dubey, S., Klütsch, C., Litvinchuk, S. N., Scheidt, U., \& Perrin, N. (2008). Mitochondrial and nuclear phylogeny of circum-Mediterranean tree frogs from the Hyla arborea group. Molecular Phylogenetics and Evolution, 49, 1019-1024. https://doi.org/10.1016/j.ympev.2008. 08.029

Stöck, M., Dufresnes, C., Litvinchuk, S. N., Lymberakis, P., Biollay, S., Berroneau, M., ... Perrin, N. (2012). Cryptic diversity among Western Palearctic tree frogs: Postglacial range expansion, range limits, and secondary contacts of three European tree frog lineages (Hyla arborea group). Molecular Phylogenetics and Evolution, 65, 1-9. https://doi.org/ 10.1016/j.ympev.2012.05.014

Swets, J. A. (1988). Measuring the accuracy of diagnostic systems. Science, 240, 1285-1293. https://doi.org/10.1126/science.3287615

Tajima, F. (1989). Statistical method for testing the neutral mutation hypothesis by DNA polymorphism. Genetics, 123, 585-595.
Teixeira, J., Gonçalves, H., Ferrand, N., García-París, M., \& Recuero, E. (2018). Mitochondrial phylogeography of the Iberian endemic frog Rana iberica, with implications for its conservation. Current Zoology, 64, 755-764. https://doi.org/10.1093/cz/zoy010

Villesen, P. (2007). FaBox: An online toolbox for FASTA sequences. Molecular Ecology Notes, 7, 965-968. https://doi.org/10.1111/j.1471-8286. 2007.01821.x

Waters, J. M., Fraser, C. I., \& Hewitt, G. M. (2013). Founder takes all: Density-dependent processes structure biodiversity. Trends in Ecology and Evolution, 28, 78-85. https://doi.org/10.1016/j.tree.2012.08.024

Zadeh, L. A. (1965). Fuzzy sets. Information and control, 8, 338-353. https://doi.org/10.1016/S0019-9958(65)90241-X

\section{BIOSKETCHES}

The research group has an interest in developing and applying model-based genetic analyses and species distribution modelling (SDM) to address the study of demographic processes and assess their role in driving biodiversity patterns.

Author contributions: I.M.S., E.R.G., and A.M.B. designed the research. I.M.S., E.R.G., A.M.B. and G.S.M. conducted field work and sample collection. E.R.G. and G.S.M. conducted laboratory work. I.M.S. and G.S.M. performed the genetic analyses. A.M.B. performed the SDM analyses. G.S.M. wrote the manuscript and E.R.G., A.M.B. and I.M.S. provided edits to the manuscript.

\section{SUPPORTING INFORMATION}

Additional supporting information may be found online in the Supporting Information section at the end of the article.

How to cite this article: Sánchez-Montes G, Recuero E, Barbosa AM, Martínez-Solano Í. Complementing the Pleistocene biogeography of European amphibians: Testimony from a southern Atlantic species. J Biogeogr. 2019;00:1-16. https://doi.org/10.1111/jbi.13515 